\title{
Modeling ozone plumes observed downwind of New York City over the North Atlantic Ocean during the ICARTT field campaign
}

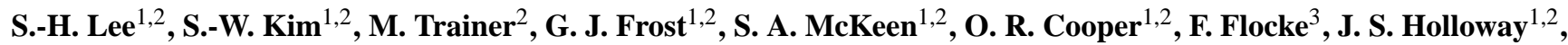 \\ J. A. Neuman ${ }^{1,2}$, T. Ryerson ${ }^{2}$, C. J. Senff ${ }^{1,2}$, A. L. Swanson ${ }^{4}$, and A. M. Thompson ${ }^{5}$ \\ ${ }^{1}$ Cooperative Institute for Research in Environmental Sciences, University of Colorado, Boulder, Colorado, USA \\ ${ }^{2}$ NOAA Earth System Research Laboratory, Boulder, Colorado, USA \\ ${ }^{3}$ National Center for Atmospheric Research, Boulder, Colorado, USA \\ ${ }^{4}$ Northrop Grumman Corporation, California, USA \\ ${ }^{5}$ Department of Meteorology, Pennsylvania State University, Pennsylvania, USA
}

Received: 22 March 2011 - Published in Atmos. Chem. Phys. Discuss.: 6 May 2011

Revised: 20 July 2011 - Accepted: 20 July 2011 - Published: 26 July 2011

\begin{abstract}
Transport and chemical transformation of welldefined New York City (NYC) urban plumes over the North Atlantic Ocean were studied using aircraft measurements collected on 20-21 July 2004 during the ICARTT (International Consortium for Atmospheric Research on Transport and Transformation) field campaign and WRF-Chem (Weather Research and Forecasting-Chemistry) model simulations. The strong NYC urban plumes were characterized by carbon monoxide (CO) mixing ratios of 350-400 parts per billion by volume (ppbv) and ozone $\left(\mathrm{O}_{3}\right)$ levels of about 100 ppbv near New York City on 20 July in the WP-3D in-situ and DC-3 lidar aircraft measurements. On 21 July, the two aircraft captured strong urban plumes with about 350 ppbv $\mathrm{CO}$ and over 150 ppbv $\mathrm{O}_{3}(\sim 160$ ppbv maximum) about $600 \mathrm{~km}$ downwind of NYC over the North Atlantic Ocean. The measured urban plumes extended vertically up to about $2 \mathrm{~km}$ near New York City, but shrank to $1-1.5 \mathrm{~km}$ over the stable marine boundary layer (MBL) over the North Atlantic Ocean. The WRF-Chem model reproduced ozone formation processes, chemical characteristics, and meteorology of the measured urban plumes near New York City (20 July) and in the far downwind region over the North Atlantic Ocean (21 July). The quasi-Lagrangian analysis of transport and chemical transformation of the simulated NYC urban plumes using WRF-Chem results showed that the pollutants can be efficiently transported in (isentropic) layers in the lower atmosphere $(<2-3 \mathrm{~km})$ over the
\end{abstract}

Correspondence to: S.-H. Lee (nihil93@snu.ac.kr)
North Atlantic Ocean while maintaining a dynamic vertical decoupling by cessation of turbulence in the stable MBL. The $\mathrm{O}_{3}$ mixing ratio in the NYC urban plumes remained at $80-90 \mathrm{ppbv}$ during nocturnal transport over the stable MBL, then grew to over $100 \mathrm{ppbv}$ by daytime oxidation of nitrogen oxides $\left(\mathrm{NO}_{\mathrm{x}}=\mathrm{NO}+\mathrm{NO}_{2}\right)$ with mixing ratios on the order of $1 \mathrm{ppbv}$. Efficient transport of reactive nitrogen species $\left(\mathrm{NO}_{\mathrm{y}}\right)$, specifically nitric acid $\left(\mathrm{HNO}_{3}\right)$, was confirmed through the comparison of the $\mathrm{CO} / \mathrm{NO}_{\mathrm{y}}$ ratio in photochemically fresh and aged NYC plumes, implying the possibility of long-range transport of $\mathrm{O}_{3}$ over the stable MBL over the North Atlantic Ocean in association with $\mathrm{NO}_{\mathrm{x}}$ regeneration mechanism. The impact of chemical initial and boundary conditions (IC/BCs) on modelled $\mathrm{O}_{3}$ urban plumes was investigated in terms of the background $\mathrm{O}_{3}$ level and the vertical structure of the urban plumes. Simulations with dynamic ("time-variant") chemical IC/BCs enhanced the $\mathrm{O}_{3}$ level by $2-12 \mathrm{ppbv}$ on average in the atmospheric layer below $3 \mathrm{~km}$, showing better agreement with the observed NYC plumes and biomass-burning plumes than the simulation with prescribed static IC/BCs. The simulation including MOZART-4 chemical IC/BCs and Alaskan/Canadian wildfire emissions compared better to the observed $\mathrm{O}_{3}$ profiles in the upper atmospheric layer $(>\sim 3 \mathrm{~km})$ than models that only accounted for North American anthropogenic/biogenic and wildfire contributions to background ozone. The comparison between models and observations show that chemical IC/BCs must be properly specified to achieve accurate model results.

Published by Copernicus Publications on behalf of the European Geosciences Union. 


\section{Introduction}

Major primary pollutants such as nitrogen oxides $\left(\mathrm{NO}_{\mathrm{x}}=\right.$ $\left.\mathrm{NO}+\mathrm{NO}_{2}\right)$, carbon monoxide $(\mathrm{CO})$, sulfur dioxide $\left(\mathrm{SO}_{2}\right)$, and particulate matter are emitted at or near the surface in urban areas. Oxidation of the primary emitted pollutants forms secondary pollutants, such as ozone $\left(\mathrm{O}_{3}\right)$, through photochemical reactions. These primary and secondary pollutants directly affect air quality and human health in urban areas. In addition, emissions and their products exported from urban areas can have large-scale impacts on background levels of pollutants downwind of urban areas through transport on local $(\sim 10-100 \mathrm{~km})$, regional $(\sim 100-1000 \mathrm{~km})$, and global scales $(>1000 \mathrm{~km})$ (e.g. Daum et al., 1996; Jacob et al., 1999; Parrish et al., 1998; Li et al., 2002; Angevine et al., 2004; Owen et al., 2006; Cooper et al., 2010). Long-range transport from remote pollution sources can significantly impact attainment of local air-quality standards (e.g. Park et al., 2004; Auvray and Bey, 2005; Wang et al., 2009a). Therefore, understanding the transport and chemical evolution of urban plumes in the troposphere is essential for accurate prediction of air quality at a variety of spatial scales.

Considerable effort to understand the transport processes and associated chemical transformation have been made through several large-scale field campaigns and model simulations, especially over North America and the North Atlantic Ocean (Table 1 in Fehsenfeld et al., 2006). Li et al. (2005) calculated that approximately $38 \%$ of the summertime North American CO export occurs below $3 \mathrm{~km}$. Owen et al. (2006) suggested that low-altitude $(<\sim 3 \mathrm{~km})$ transport of pollutants from North America above the marine boundary layer (MBL) may provide an effective mechanism for this export. Through the analysis of reactive nitrogen compounds from aircraft measurements during the ICARTT (International Consortium for Atmospheric Research on Transport and Transformation) field campaign (Fehsenfeld et al., 2006; Singh et al., 2006), Neuman et al. (2006) found that the pollutants emitted from the urban corridor of the northeastern US can be efficiently transported hundreds of km downwind over the North Atlantic Ocean. Mao et al. (2006) analyzed in-situ $\mathrm{O}_{3}$ measurements obtained from semi-Lagrangian balloons in which high $\mathrm{O}_{3}$ mixing ratios over the North Atlantic, compared to the northeastern US, were captured during the transport of urban plumes. Real et al. (2008) used a Lagrangian analysis of the ICARTT measurements to show that urban plumes originating from the New York City (NYC)-Boston region reach Western Europe. Efficient transport of nitric acid $\left(\mathrm{HNO}_{3}\right)$, a major product of $\mathrm{NO}_{\mathrm{x}}$ oxidation in urban plumes (Trainer et al., 1995), can play an important role in maintaining $\mathrm{O}_{3}$ levels in the plumes carried across the Atlantic through $\mathrm{NO}_{\mathrm{x}}$ regeneration and photochemical production (Neuman et al., 2006; Real et al., 2008). In those studies, efficient low-level long-range transport was attributed to the existence of an atmospheric inversion layer over the North Atlantic Ocean, which had been identified by previous measurements over the region that showed MBL heights less than $\sim 100 \mathrm{~m}$ (e.g. Daum et al., 1996; Angevine et al., 1996, 2004). Angevine et al. (2006) examined meteorological characteristics and associated transport processes over the northeastern US using a three-dimensional meteorological model in which the New York City and Boston emissions were considered as tracers. They also attributed model-measurement discrepancies and the difficulty of simulating stable boundary layers to atmospheric boundary layer (ABL) processes.

Here, we characterize fine-resolution horizontal and vertical structures in the NYC urban plumes using aircraft measurements, and explain the low-level transport mechanism and photochemical transformation processes of the urban plumes over the North Atlantic Ocean using a coupled meteorology-chemistry model. We also investigate the impact of chemical initial and boundary conditions (IC/BCs) on the plume simulations over the northeastern US.

A case of well-defined NYC urban plumes is selected and investigated in the aircraft measurements from the New England Air Quality Study (NEAQS) and Intercontinental Transport and Chemical Transformation (ITCT) study. The NEAQS-ITCT, conducted by NOAA as one component of ICARTT, deployed two research aircraft, the NOAA WP-3D and the DC-3, in combination with the NOAA Research Vessel Ronald H. Brown. The WP-3D aircraft made in-situ measurements of a number of trace gases and aerosols as well as meteorology over the northeastern US urban areas (New York City and Boston) and the North Atlantic Ocean (the Gulf of Maine). The lidar instrument onboard the DC-3 aircraft mapped the horizontal and vertical distributions of atmospheric ozone and aerosols below $3 \mathrm{~km}$ altitude, covering areas similar to those observed by the WP-3D. The integrated measurements of meteorology and chemical species give a unique opportunity to understand the low-level transport of pollutants from New York City over the North Atlantic Ocean.

In this study we use the WRF-Chem (Weather Research and Forecasting-Chemistry) model to interpret these observations and to understand transport and transformation processes. The model's performance in simulating transport and chemical transformation of the urban plumes over the Northeastern US region is assessed by comparison to the observations. In addition, output from a global chemical transport model, emissions from Alaskan/Canadian wildfires, and North American anthropogenic/biogenic emissions are included as chemical IC/BCs using a dynamic downscaling approach for chemistry (Song et al., 2008).

The manuscript is presented as follows. Section $2 \mathrm{de}-$ scribes the selected urban plume case and synoptic meteorological conditions. Section 3 describes the coupled meteorology-chemistry model and its physical and chemical process configurations for the simulations, including chemical IC/BCs considered. Section 4 presents the characteristics of urban and biomass-burning (BB) plumes observed from 
Table 1. Physical and chemical processes used for WRF-Chem model domain $1(27 \mathrm{~km})$, domain 2 (9 km), and domain 0 (60 km).

\begin{tabular}{|c|c|c|}
\hline Category & Setup (domains 1 and 2) & Setup (domain 0) \\
\hline Shortwave radiation & Simple shortwave scheme (Dudhia, 1989) & Simple shortwave scheme \\
\hline Longwave radiation & RRTM (Mlawer et al., 1997) & RRTM \\
\hline Turbulence & Mellor-Yamada-Janjic scheme (Janjic, 1990) & Mellor-Yamada-Janjic scheme \\
\hline Land surface process & $\begin{array}{l}\text { Noah LSM with UCM } \\
\text { (Chen and Dudhia, 2001) }\end{array}$ & Noah LSM with UCM \\
\hline Grid-scale clouds & $\begin{array}{l}\text { WRF single-moment 5-class scheme (Hong et } \\
\text { al., 2004) }\end{array}$ & WRF single-moment 5-class scheme \\
\hline Subgrid-scale clouds & $\begin{array}{l}\text { Grell-Devenyi ensemble scheme } \\
\text { (Grell and Devenyi, 2002) (Domain } 1 \text { only) }\end{array}$ & Grell 3d cumulus ensemble scheme \\
\hline Advection & $\begin{array}{l}\text { Positive definite and monotonic scheme (Wang } \\
\text { et al., 2009b) }\end{array}$ & Positive definite and monotonic scheme \\
\hline Gas chemistry & RACM (Stockwell et al., 1997) & RACM \\
\hline Aerosol & $\begin{array}{l}\text { MADE (Ackermann et al., 1998) } \\
\text { SORGAM (Schell et al., 2001) }\end{array}$ & MADE/SORGAM \\
\hline Photolysis & TUV (Madronich, 1987) & TUV \\
\hline Anthropogenic emission & NEI05 & NEI05 \\
\hline Biogenic emission & BEIS 3.13 & MEGAN2 \\
\hline
\end{tabular}

the research aircraft in comparison with the model-simulated plumes, identifies the sources of the urban plumes, and explains the characteristics of low-level transport and chemical transformation using the model simulations. Sensitivity analyses for different chemical IC/BCs are also presented in Sect. 4 , followed by a summary and conclusions in Sect. 5.

\section{Selection of a case study}

The main research objectives of the NEAQS-ITCT field study included (1) the verification of emissions from cities (e.g. New York City and Boston), point sources (e.g. Ohio River Valley power plants), and biogenic sources in the eastern US, (2) the characterization of local and long-range transport and turbulent mixing processes of anthropogenic pollutants exported from the North American continental (convective) boundary layer, including intercontinental transport to Europe, (3) the understanding of the chemical transformation of the primary pollutants forming secondary pollutants such as ozone, and (4) the performance evaluation of air quality models. The NOAA WP-3D aircraft and the DC-3 lidar aircraft deployed extensive instrumentation to characterize atmospheric chemical constituents and meteorology over the eastern US and the North Atlantic Ocean, especially in the lowest layer of the atmosphere $(<3-4 \mathrm{~km})$ (see Figs. A1 and A2 in Fehsenfeld et al. (2006) for the WP-3D and DC-3 flight tracks during ICARTT). The WP-3D aircraft conducted a total of 18 flights between 5 July and 15 August 2004 based out of Portsmouth, New Hampshire. In this study two flights that focused on the NYC urban plumes near the source region and in downwind areas are investigated in detail. The 20 July and
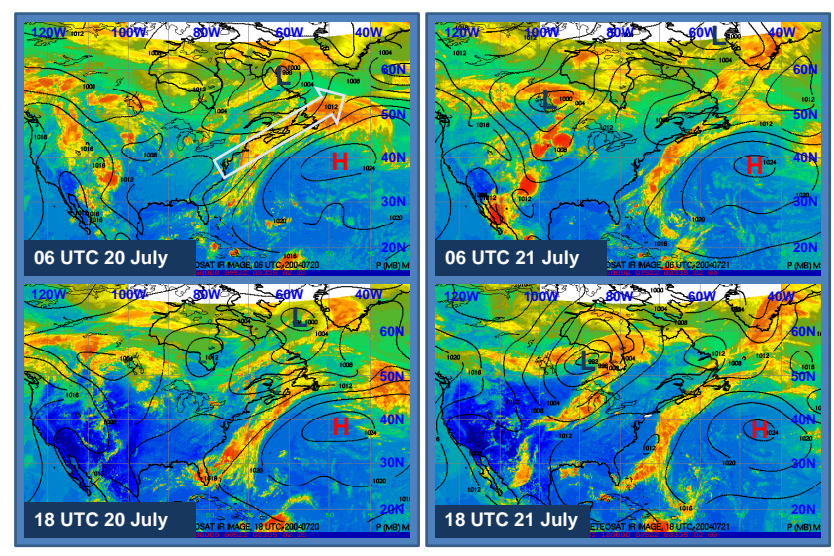

Fig. 1. Infrared images combined from GOES-WEST, GOESEAST, and METEOSAT-7 geostationary satellites over North America and the North Atlantic Ocean on 20 and 21 July with a 12-h interval. Contours indicate mean sea level pressure in $\mathrm{hPa}$. A white arrow indicates an export pathway of the North America pollutants in association with transient mid-latitude cyclones and a stationary maritime high pressure system in the North Atlantic Ocean.

21 July flights measured the chemical composition of fresh NYC urban plumes intercepted over Long Island and in aged NYC plumes over the Gulf of Maine, respectively. In addition, distinctive biomass-burning signals were also captured at about $3 \mathrm{~km}$ altitude over Pennsylvania on 20 July and over Cape Cod on 21 July.

WP-3D measurements of $\mathrm{O}_{3}, \mathrm{CO}, \mathrm{HNO}_{3}, \mathrm{NO}_{\mathrm{x}}$, and total reactive nitrogen species $\left(\mathrm{NO}_{\mathrm{y}}=\mathrm{NO}+\mathrm{NO}_{2}+\mathrm{HNO}_{3}\right.$ + peroxyacetyl nitrates (PANs) ) are analyzed to characterize 
the urban plume and its photochemical evolution. The WP$3 \mathrm{D}$ data have approximately $100-\mathrm{m}$ horizontal and 5-m vertical resolutions, based on the normal aircraft speed. In the area where the WP-3D encountered the NYC plumes on both days, the DC-3 lidar aircraft remotely measured several ozone urban plumes near New York City (20 July) and far downwind of the source areas (21 July) with 600-m horizontal and 90-m vertical resolutions. In addition, measured meteorological variables such as potential temperature, specific humidity, and wind fields from the WP-3D and the DC3 (drop-sondes) are also analyzed for the model evaluation and the meteorological characterization of the atmosphere over the North Atlantic Ocean. The aircraft measurements with high spatial and temporal resolutions were projected on the model grid, and then median values of the observations at each model grid point were selected and compared to the simulated values. Measurements details including instrument payloads in each aircraft can be found in Fehsenfeld et al. (2006).

Synoptic meteorological conditions for the two selected days were dominated by the North Atlantic ("Bermuda") High sitting in region of $40^{\circ} \mathrm{W}-50^{\circ} \mathrm{W}$ and $35^{\circ} \mathrm{N}-45^{\circ} \mathrm{N}$ (Fig. 1). After the passage of a low pressure system, the NYC metropolitan area had fair weather conditions. Surface warm and cold fronts associated with the cyclonic flow, which account for most of the pollutant export from North America (Cooper et al., 2002; Li et al., 2005; Fang et al., 2009), swept air pollutants northeastward to Nova Scotia. Therefore, the selected days are favorable to examine the transport and chemical transformation processes of urban plumes released from the NYC metropolitan area.

\section{Model description and experimental design}

\subsection{WRF-Chem model and experimental setup for control simulation}

The WRF-Chem model (Version 3.1) used in this study is an online extension of the WRF model for chemistry (Grell et al., 2005). Anthropogenic and biogenic emissions, gas and aqueous phase chemical transformation, aerosol formation, and dry/wet deposition are coupled with the WRF meteorology model. Therefore, all conservative chemical properties are consistently transported by modeled meteorology. The WRF model is a three-dimensional, fully compressible, nonhydrostatic meteorological model with an Arakawa-C grid system and a terrain-following pressure coordinate. It also has one-way or two-way nesting capability for a high resolution simulation in the area of interest. The WRF model includes various physical processes of radiation, turbulent mixing, grid-scale microphysics, subgrid-scale convection, and land-atmosphere interaction (Skamarock et al., 2008).

For the transport and chemical transformation simulations in this study, the WRF-Chem model is configured with two
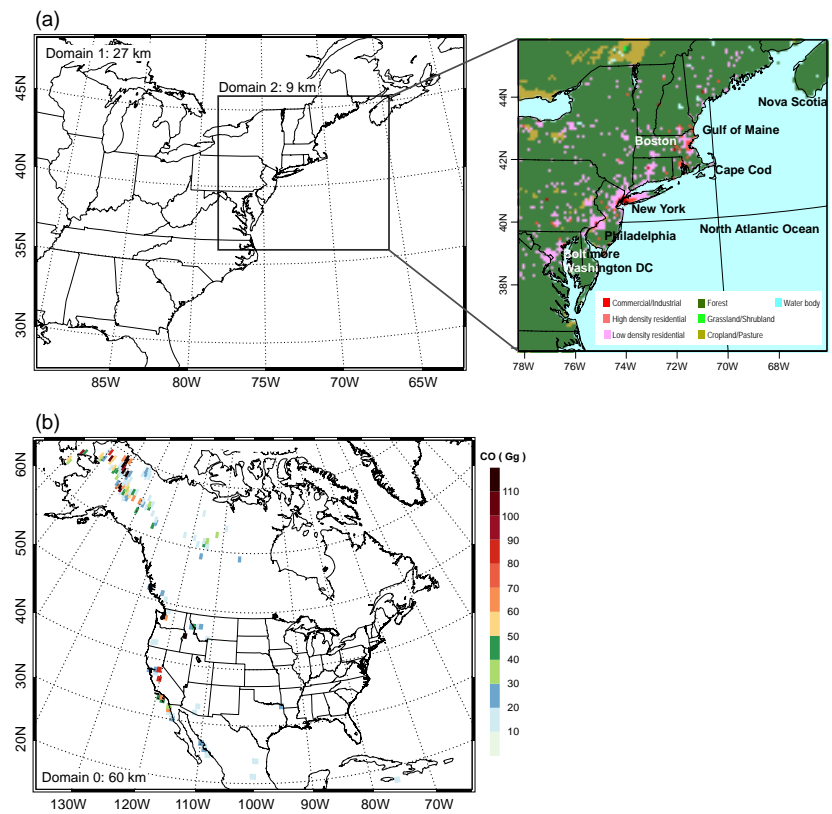

Fig. 2. (a) Configuration of WRF-Chem domains for control simulations. The coarse domain (domain 1) has a horizontal resolution of $27 \mathrm{~km}(100 \times 86 \mathrm{mesh})$, and the nested domain (domain 2$)$ has a horizontal resolution of $9 \mathrm{~km}(121 \times 121 \mathrm{mesh})$. The nested domain 2 shows a spatial distribution of dominant land-use type based on the USGS (United States Geological Survey) land-use data for natural surfaces and the NLCD (National Land Cover Dataset 2001) for three urban classes. (b) A larger WRF-Chem domain (domain $0)$ with a horizontal resolution of $60 \mathrm{~km}(135 \times 115 \mathrm{mesh})$ designed to provide chemical initial and boundary conditions for the $27 \mathrm{~km}$ domain. A spatial distribution of total $\mathrm{CO}$ emissions from wildfires during the period of 12-19 July 2004 is shown.

domains (Fig. 2a). The coarse domain (domain 1) has a horizontal resolution of $27 \mathrm{~km}(100 \times 86$ mesh $)$ covering the eastern US and the North Atlantic Ocean (Fig. 2). The nested domain (domain 2) has a $9 \mathrm{~km}$ horizontal grid spacing $(121 \times 121 \mathrm{mesh})$ including the major metropolitan areas of the northeastern US such as New York City, Boston, Philadelphia, Baltimore, and Washington DC. The vertical grid is composed of 41 full sigma levels stretching from near surface ( $\sim 12 \mathrm{~m}$ at the first half sigma level) to the model top $(50 \mathrm{hPa})$. A one-way nesting approach is used for all simulations, in which two model grids are integrated concurrently without feedback between the coarse grid and the nested grid (Skamarock et al., 2008).

Table 1 lists the physical and chemical processes used for each domain. The WRF model uses a simple shortwave radiation scheme (Dudhia, 1989) and the RRTM (Rapid Radiative Transfer Model) for longwave radiation (Mlawer et al., 1997). Vertical turbulent diffusion is calculated using the Mellor-Yamada-Janjic (MYJ) scheme, a 1.5-order turbulence closure scheme predicting turbulent kinetic energy (TKE) (Janjic, 1990). Grid-scale clouds are resolved using 
a single-moment bulk microphysics scheme (Hong et al., 2004), in which five water species (water vapor, cloud, rain, ice, and snow) are considered. Subgrid-scale convective clouds in the coarse domain are parameterized by the GrellDevenyi ensemble scheme (Grell and Devenyi, 2002). Turbulent exchanges of momentum and energy in the interface between the surface and the overlying atmosphere are calculated using the Noah land surface model (LSM) (Chen and Dudhia, 2001), which provides the physical bottom boundary conditions of the WRF model governing equations. The urban areas in the model domains are remapped using the National Land Cover Dataset (NLCD) 2001, by which urban areas are classified into three sub-classes of commercial/industrial area, high-density residential area, and lowdensity residential area (Fig. 2a). Momentum and energy exchanges in urban patches are calculated using a singlelayer urban canopy model (UCM) in combination with the updated urban land-use mapping. When this urban parameterization was used in WRF-Chem simulations over the NYC metropolitan area, the observed chemical species (e.g. CO, $\mathrm{O}_{3}, \mathrm{NO}_{\mathrm{x}}$ ) as well as meteorology near New York City were better reproduced compared to simulations without the urban parameterization (Lee et al., 2009).

This study uses the RACM gas-phase chemistry mechanism (Stockwell et al., 1997) with the MADE/SORGAM aerosol module (Ackermann et al., 1998; Schell et al., 2001). The RACM mechanism includes 73 chemical species and 237 chemical reactions. The Kinetic PreProcessor (KPP) method (Damian et al., 2002) is used to generate the code of the RACM mechanism compatible with the WRF-Chem model. Photolysis rates for chemical species are calculated using the TUV (Tropospheric Ultraviolet-Visible) scheme (Madronich, 1987) which takes simulated ozone, hydrometeors, and aerosols into account in solving the radiative transfer equations. The US Environmental Protection Agency (EPA) National Emission Inventory 2005 (NEI05) was used for anthropogenic area emissions (including mobile sources). This version of the NEI05 consists of gridded hourly emissions for seven primary pollutant sources $\left(\mathrm{CO}, \mathrm{NO}_{\mathrm{x}}, \mathrm{SO}_{2}, \mathrm{NH}_{3}\right.$, $\mathrm{PM}_{2.5}, \mathrm{PM}_{10}$, and VOC) covering the US, southern Canada, and northern Mexico. Hourly emissions of $\mathrm{NO}_{\mathrm{x}}$ and $\mathrm{SO}_{2}$ for many large US point sources were obtained from 2006 Continuous Emissions Monitoring System (CEMS) data. Biogenic emissions are calculated using the Biogenic Emissions Inventory System (BEIS) Version 3.13 which updates the emissions during the model integration according to the model simulated temperature and radiation at each vegetation type.

The advection of all conservative scalars (e.g. hydrometeors, chemical species, TKE) is calculated using the thirdorder Runge-Kutta time-integration scheme in combination with space discretization of advective fluxes with fifth-order accuracy in the horizontal direction and third-order accuracy in the vertical direction (Skamarock et al., 2008). The monotonic flux limiter based on flux renormalization is ap- plied for the conservative scalars in order to satisfy positivedefiniteness (i.e. not allowing negative values) and monotonicity (i.e. not allowing spurious local minima and maxima) (Wang et al., 2009b).

The NCEP (National Centers for Environmental Prediction) final analysis (FNL) data (horizontal resolution $1^{\circ} \times 1^{\circ}$ ) with 6-h intervals are used as meteorological initial and boundary conditions. The meteorological fields (winds, temperature, and specific humidity) from the FNL data are nudged in the levels above the ABL height during the model integration using a Newtonian nudging approach. Initial mixing ratios of chemical species are assigned following McKeen et al. (2002) and Liu et al. (1996) which consist of spatio-temporally invariant vertical profiles of gaseous and aerosol components representing Northern Hemispheric, mid-latitude, clean environmental conditions. $\mathrm{O}_{3}$ mixing ratios are set to $30 \mathrm{ppbv}$ from the surface to about $500 \mathrm{~m}$, increasing gradually to $60 \mathrm{ppbv}$ at $12 \mathrm{~km}$, then increasing exponentially to about $170 \mathrm{ppbv}$ at $15 \mathrm{~km}$ which remains constant to the model top $(\sim 20 \mathrm{~km})$. CO conditions are set to $80 \mathrm{ppbv}$ homogeneously up to $14 \mathrm{~km}$, then decreasing exponentially to $70 \mathrm{ppbv}$ at the model top. Based on the prescribed time-invariant ("static") vertical profiles, the model lateral boundary mixing ratios of chemical species are determined by constant inflow and zero-gradient outflow conditions (Skamarock et al., 2008).

The control simulation with the above model configuration is conducted for four days from 00:00 UTC 18 July 2004 to 00:00 UTC 22 July 2004, during the ICARTT field campaign. The model is run continuously for the simulation period with a two-day spin-up on 18-19 July. Sea surface temperatures are taken from the NCEP FNL data, being held constant as initial conditions during the simulation period. The analyses of simulated meteorology and chemical plumes, shown in Sects. 4.1-4.3, are based on the nested domain $(9 \mathrm{~km}$ resolution) of the control simulation.

\subsection{Experimental setup for dynamic ("time-variant") chemical IC/BCs}

In order to investigate the impact of chemical IC/BCs on the simulation of the NYC ozone plumes, a separate WRF-Chem domain with a horizontal resolution of $60 \mathrm{~km}(135 \times 115$ mesh), which is designed to provide initial mixing ratios and time-variant lateral boundary conditions of gaseous and aerosol components for the $27 \mathrm{~km}$ domain, is configured covering the whole US, Canada, and Mexico (Fig. 2b). This domain is large enough to represent Alaskan/Canadian forest fires that occurred during the ICARTT field campaign period. The vertical grid of the $60 \mathrm{~km}$ domain consists of 41 sigma levels with the same vertical spacing of the $27 \mathrm{~km}$ domain. The RACM gas-phase chemistry in combination with the MADE/SORGAM aerosol mechanism is used for the $60 \mathrm{~km}$ model domain, consistent with the $27 \mathrm{~km}$ domain. Most meteorological and chemical processes used for the 
$60 \mathrm{~km}$ domain are also identical to those of the $27 \mathrm{~km}$ domain (Table 1). Therefore, the calculated chemical species from the $60 \mathrm{~km}$ domain are identical with those in the $27 \mathrm{~km}$ domain, and they are provided to the $27 \mathrm{~km}$ domain as chemical IC/BCs without any of the chemical mapping that is commonly required using a global chemical transport model output (e.g. Song et al., 2008; Tang et al., 2009). This design of an intermediate ("buffer") domain may be of benefit in reducing potential errors caused by inconsistencies in chemical mechanism as well as in model horizontal/vertical grid resolutions between different two models when chemical IC/BCs from a coarse global chemical transport model are used.

Three simulations with the $60 \mathrm{~km}$ domain configuration are conducted: (1) simulation with chemical IC/BCs using the MOZART-4 (Model for Ozone and Related Chemical Tracers Version 4) model and wildfire emissions ("MOZART_BB"); (2) simulation with chemical IC/BCs using prescribed profiles and wildfire emissions ("WRF60k_BB"); and (3) simulation with chemical IC/BCs using prescribed profiles without wildfire emissions ("WRF60k"). The WRF-Chem model in the $60 \mathrm{~km}$ simulations is integrated for 12 days from 00:00 UTC 11 July to 00:00 UTC 23 July using meteorological IC/BCs of the NCEP FNL, which are nudged during the simulation period. The integration time span of the $60 \mathrm{~km}$ domain was determined by backward trajectory analysis of a biomass-burning plume captured on 20 July by the NOAA WP-3D aircraft, which showed that the BB plume originated in Alaska around 13 July.

The MOZART-4 model is a global chemical transport model for the troposphere that includes 85 gas-phase species, 12 bulk aerosol compounds, 39 photolysis reactions, and 157 gas-phase reactions (Emmons et al., 2010). This study uses outputs obtained from the MOZART- 4 model with a horizontal resolution of approximately $2.8^{\circ} \times 2.8^{\circ}$ and 28 vertical levels from near surface to approximately $2 \mathrm{hPa}$. A software package developed by the National Center for Atmospheric Research (NCAR) was used to generate chemical initial fields and time-varying boundary conditions compatible with the WRF-Chem chemistry from the MOZART-4 model outputs (http://www.acd.ucar.edu/wrf-chem/).

Wildfire emissions were calculated first on a daily basis using the Brazilian biomass burning emission model (Freitas et al., 2005; Longo et al., 2010), in which wildfireemitted tracer mass for a certain species is estimated from the multiplicative product of combustion efficiency, biomassfuel loading, the emission factor for a certain species, and the burned area. The emission factors (fraction of emitted mass per biomass fuel mass burned) and combustion factors were calculated based on Andreae and Merlet (2001) and Ward et al. (1992). The fire locations and burned area were obtained from a combination of three satellite data sets: the Geostationary Operational Environmental Satellite-Wildfire Automated Biomass Burning Algorithm (GOES WF_ABBA) fire product (Prins et al., 1998), the Moderate Resolution Imag-

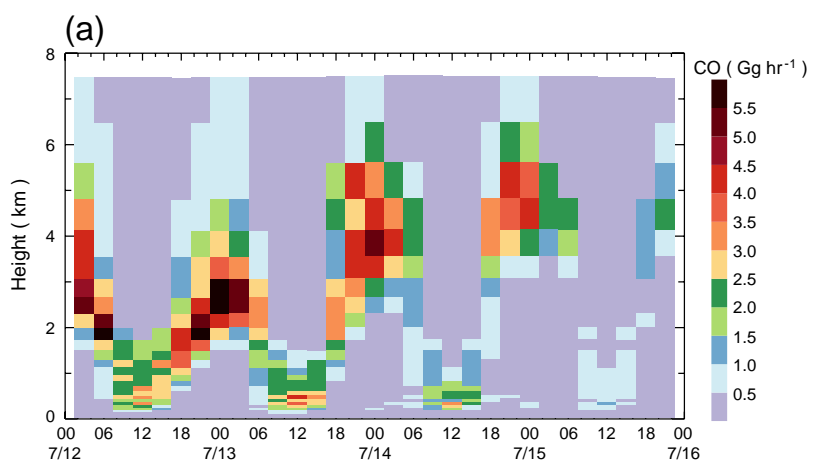

(b)

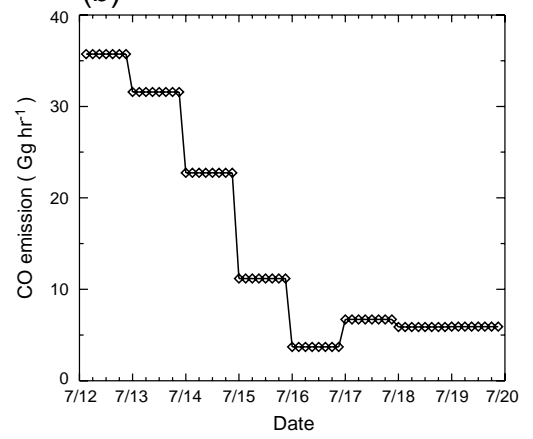

(c)

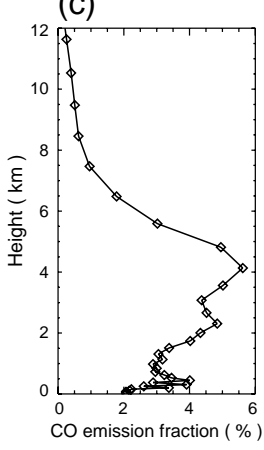

Fig. 3. (a) Vertical and temporal distribution of the model-estimated wildfire CO emissions in Alaska from 12 July to 15 July. (b) Temporal distribution of the wildfire $\mathrm{CO}$ emissions averaged over the Alaska area from 12 July to 19 July. (c) Mean vertical fraction of the injected wildfire $\mathrm{CO}$ emissions averaged over Alaska during the same time period.

ing Spectroradiometer (MODIS) fire product (Giglio et al., 2003), and the Advanced Very High Resolution Radiometer (AVHRR) fire product from NOAA polar-orbiting satellites (Pu et al., 2007). The calculated wildfire emissions were adjusted by matching to the $\mathrm{CO}$ emission amount estimated from a bottom-up fire emission inventory (Turquety et al., 2007). Injection heights of wildfire emissions are determined during the simulation by solving an embedded 1dimensional plume-rise model (Freitas et al., 2005) using a super-parameterization concept (Grabowski, 2001). Plumerise calculation was updated every $30 \mathrm{~min}$ during the simulation.

The spatial distribution of total estimated $\mathrm{CO}$ emissions from wildfires during the period of 12-19 July is shown in Fig. 2b. Major $\mathrm{CO}$ emissions are found in Alaska $\left(125^{\circ} \mathrm{W}-\right.$ $170^{\circ} \mathrm{W}$ ) with a total of about $3.7 \mathrm{Tg} \mathrm{CO}$ emitted during the period. This amount is about $16 \%$ of the total wildfire CO emissions $(23.6 \mathrm{Tg})$ over the Alaska-Yukon region during ICARTT estimated in Turquety et al. (2007). Figure 3 shows detailed spatial and temporal distributions of wildfire $\mathrm{CO}$ emissions averaged over the Alaskan area. The calculated injection heights of wildfire $\mathrm{CO}$ emissions show a distinctive diurnal variation (Fig. 3a). The wildfire $\mathrm{CO}$ emissions 
are distributed in an atmospheric layer ranging from $2 \mathrm{~km}$ to $6 \mathrm{~km}$ during the daytime, while their injection heights are relatively low, ranging from several hundred meters to $2 \mathrm{~km}$, in the stably stratified atmosphere during the night. This characteristic diurnal variation in the injection height of wildfire plumes is similar to the results for forest fires obtained from a 1-dimensional plume-rise model (see Fig. 7 in Freitas et al., 2007). The largest wildfire $\mathrm{CO}$ emissions were estimated on 12 July with a rate of about $35 \mathrm{Gg} \mathrm{h}^{-1}$ during the simulation period, gradually decreasing to about $5 \mathrm{Gg} \mathrm{h}^{-1}$ in several days (Fig. 3b). A maximum of about $6 \%$ of the total estimated $\mathrm{CO}$ emissions were released in a layer around $4 \mathrm{~km}$ altitude (Fig. 3c).

\section{Results}

\subsection{Evaluation of model meteorology}

The model-simulated meteorology on 20 and 21 July is evaluated with measurements from the WP-3D aircraft and surface meteorological stations. The WP-3D flights were conducted mostly within the ABL (below $1.5 \mathrm{~km}$ ), often reaching up to about 3-4 km for vertical profiles, during the daytime (around 14:00-21:00 UTC). On 21 July, most of the WP-3D flight took place over the North Atlantic (the Gulf of Maine), including several horizontal transects below $0.5 \mathrm{~km}$ altitude. Four surface meteorological stations near New York City were also used for model evaluation. Stations JFK (John F Kennedy International Airport) and LGA (La Guardia International Airport) are located in urban areas on Long Island, and stations 44025 (buoy station) and ALSN6 (Ambrose Light Station) are located off the southern part of Long Island. These stations, in combination with the WP-3D are useful to evaluate simulated local meteorological conditions near New York City, where fresh urban plumes originated, and over the North Atlantic Ocean, where the aged plumes were detected.

Statistics analyzed include the determinant coefficient $\left(R^{2}\right)$, mean bias error (MBE), and root mean square error (RMSE) with its systematic component $\left(\mathrm{RMSE}_{\mathrm{s}}\right)$, which are formally defined in Lee (2011) from Willmott (1981). The $\mathrm{RMSE}_{\mathrm{S}}$ is associated with systematic errors that can be corrected by model physics and/or input parameters, and the $\mathrm{RMSE}_{\mathrm{s}}^{2} / \mathrm{RMSE}^{2}$ is a useful measure indicating a systematic fraction of total error ranging from 0 to 1 . Table 2 shows statistical evaluation results from the WRF-Chem simulation and the WP-3D measurement. The observed and simulated meteorology are well correlated on both days with $R^{2}=0.98-0.99$ in temperature and $R^{2}=0.88-0.92$ in specific humidity. The simulated wind fields compare quite well to the observed fields, especially wind direction with $R^{2}=0.87-0.88$. The underestimation of simulated temperatures $\left(\mathrm{MBE}=-1.7^{\circ} \mathrm{C}\right.$ on $20 \mathrm{July}$ and $=-1.2^{\circ} \mathrm{C}$ on 21 July) is mainly associated with systematic errors, having
$\mathrm{RMSE}_{\mathrm{S}}^{2} / \mathrm{RMSE}^{2}$ of about 0.8 , while the error in simulated specific humidity (MBE $=-0.4 \mathrm{~g} \mathrm{~kg}^{-1}$ on both the days) is relatively non-systematic (random). The systematic error in the temperature field is partly attributed to meteorological IC/BCs from the NCEP FNL data.

Table 3 shows statistical evaluation results against the four surface meteorological stations. The simulated 2-m air temperatures at the two urban stations compare well with the observations, with MBEs of $0.2^{\circ} \mathrm{C}$ (station JFK) and $-0.2^{\circ} \mathrm{C}$ (station LGA) and $\mathrm{RMSE}=0.7^{\circ} \mathrm{C}$ at both stations. The observed 2-m air temperatures at the stations over the ocean were about $22-25^{\circ} \mathrm{C}$ with a diurnal variation of $1-2^{\circ} \mathrm{C}$, while the simulated $2-\mathrm{m}$ air temperatures are about $22^{\circ} \mathrm{C}$ with a smaller diurnal amplitude than the observation. The slight underestimation of about $1-2{ }^{\circ} \mathrm{C}$ and small diurnal variation in simulated $2-\mathrm{m}$ air temperature may be partly attributed to the use of static (constant) sea surface temperatures during the simulation period. The observed specific humidity is underestimated by about $1 \mathrm{~g} \mathrm{~kg}^{-1}$ in all compared stations. The surface winds on 20 July were southerly or southwesterly flows, and then changed to northerly winds on 21 July according to large-scale forcing changes. As the sea breeze develops on 21 July, the wind direction changed from northerly to westerly around 16:00-17:00 UTC (not shown). The model captured the observed wind fields with MBEs of $1-2 \mathrm{~m} \mathrm{~s}^{-1}$ for wind speed and less than $10^{\circ}$ in wind direction.

The evaluation shows that the model did reasonably well at simulating local and regional meteorology including atmospheric structures of the stable MBL demonstrated in Sect. 4.2, which drives urban plumes and chemical transformation during transport. The statistics for model performance here are comparable to those of previous mesoscale model simulations (e.g. Holt and Pullen, 2007). As will be described below, the simulated NYC urban plumes compared well with the observations obtained in the far downwind region as well as in the near source area. This also implies that the WRF model successfully reproduced the meteorological evolution in time and space, consequently enabling accurate transport and chemical transformation simulations of the urban chemical plumes.

\subsection{Characterization of New York City urban plumes}

\subsubsection{Urban plumes in the WP-3D observations and simulation}

Carbon monoxide is used to identify strong urban and biomass-burning plumes in the WP-3D measurements. Figures 4 and 5 show the observed and simulated $\mathrm{CO}$ mixing ratios along the WP-3D flight tracks on 20 and 21 July, respectively. The aircraft altitude is plotted with the green solid line in Figs. 4b and Fig. 5b. The research aircraft observed distinct $\mathrm{CO}$ plumes on both days that originated from different sources: anthropogenic plumes and biomass-burning plumes. On 20 July (Fig. 4), the research aircraft intercepted 
Table 2. Statistics from the comparison of WRF-Chem simulation with the WP-3D measured meteorology. T, $q$, WS, WD represent air temperature, specific humidity, wind speed, and wind direction, respectively. Positive values of MBE in wind direction stand for a clockwise bias from the observed wind direction.

\begin{tabular}{lrrrrrrrr}
\hline & \multicolumn{4}{c}{ 20 July } & \multicolumn{3}{c}{21 July } \\
\cline { 2 - 8 } & $\begin{array}{r}T \\
\left({ }^{\circ} \mathrm{C}\right)\end{array}$ & $\begin{array}{r}q \\
\left(\mathrm{~g} \mathrm{~kg}^{-1}\right)\end{array}$ & $\begin{array}{r}\text { WS } \\
\left(\mathrm{m} \mathrm{s}^{-1}\right)\end{array}$ & $\begin{array}{r}\text { WD } \\
(\mathrm{deg})\end{array}$ & $\begin{array}{r}T \\
\left({ }^{\circ} \mathrm{C}\right)\end{array}$ & $\begin{array}{r}q \\
\left(\mathrm{~g} \mathrm{~kg}^{-1}\right)\end{array}$ & $\begin{array}{r}\text { WS } \\
\left(\mathrm{m} \mathrm{s}^{-1}\right)\end{array}$ & $\begin{array}{r}\text { WD } \\
(\mathrm{deg})\end{array}$ \\
\hline$N$ & 1041 & 1041 & 1041 & 1041 & 496 & 496 & 478 & 478 \\
$R^{2}$ & 0.98 & 0.88 & 0.57 & 0.88 & 0.99 & 0.92 & 0.66 & 0.87 \\
$\mathrm{MBE}$ & -1.7 & -0.4 & -0.2 & -3.3 & -1.2 & -0.4 & 0.1 & 0.1 \\
$\mathrm{RMSE}$ & 1.9 & 1.3 & 2.1 & 18.4 & 1.5 & 1.4 & 1.5 & 30.3 \\
$\left(\mathrm{RMSE}_{\mathrm{s}}^{2} / \mathrm{RMSE}^{2}\right)$ & $(0.77)$ & $(0.27)$ & $(0.43)$ & $(0.07)$ & $(0.79)$ & $(0.31)$ & $(0.38)$ & $(0.17)$ \\
\hline
\end{tabular}

Table 3. Statistics from the comparison of WRF-Chem simulated meteorology with measurements from four surface meteorological stations. Positive values of MBE in wind direction stand for a clockwise bias from the observed wind direction.

\begin{tabular}{lrrrrrrrr}
\hline \multirow{2}{*}{ Station ID } & \multicolumn{2}{c}{$T\left({ }^{\circ} \mathrm{C}\right)$} & \multicolumn{2}{c}{$q\left(\mathrm{~g} \mathrm{~kg}^{-1}\right)$} & \multicolumn{2}{c}{ WS $\left(\mathrm{m} \mathrm{s}^{-1}\right)$} & \multicolumn{2}{c}{ WD $(\mathrm{deg})$} \\
\cline { 2 - 9 } & MBE & RMSE & MBE & RMSE & MBE & RMSE & MBE & RMSE \\
\hline KJFK & 0.2 & 0.7 & -1.3 & 1.6 & -2.2 & 2.5 & -3.2 & 40.2 \\
KLGA & -0.2 & 0.7 & -0.8 & 1.2 & -1.3 & 1.6 & -18.9 & 63.4 \\
44025 & -0.8 & 1.2 & -1.0 & 1.2 & 0.8 & 1.5 & -9.9 & 47.6 \\
ALSN6 & -1.6 & 1.9 & -0.9 & 1.4 & -0.8 & 1.5 & -1.1 & 27.2 \\
\hline
\end{tabular}

strong urban plumes ("New York City" plumes) with CO mixing ratios of over 350 parts per billion by volume (ppbv) immediately downwind of New York City at about $1 \mathrm{~km}$ aircraft altitude between 18:00 UTC and 19:00 UTC. After a cold frontal passage swept aged pollutants away from NYC (Fig. 1), the measured strong urban plumes from the NYC metropolitan area are easily distinguished from the background level. In addition, the aircraft captured strong $\mathrm{CO}$ plumes, reaching $400 \mathrm{ppbv}$, over Pennsylvania at about $3 \mathrm{~km}$ altitude between 17:00 UTC and 18:00 UTC. The analysis of WP-3D acetonitrile $\left(\mathrm{CH}_{3} \mathrm{CN}\right)$ measurements, an indicator of biomass-burning emission, and trajectory modeling of the plume showed that it originated from the Alaskan wildfires (de Gouw et al., 2003, 2006). On 20 July, the aircraft observed several other aged urban plumes with $\mathrm{CO}$ mixing ratios of $250 \mathrm{ppbv}$ over the Gulf of Maine.

The WRF-Chem model reproduces the location of the NYC plumes and the enhancement of $\mathrm{CO}$ mixing ratios in these plumes (Fig. 4a and b). The simulated $\mathrm{CO}$ mixing ratios along the flight track are generally lower than the observations by about $40 \mathrm{ppbv}$ on average (Fig. $4 \mathrm{~b}$ ). The underpredictions of simulated $\mathrm{CO}$ may be caused by several factors such as uncertainties in both local and remote emissions, errors in their transport to the area of interest, other physical and chemical processes. On the other hand, the WRF-Chem model fails to reproduce the $\mathrm{CO}$ enhancement in the measured BB plumes (Fig. 4a and b). This result is expected be- cause the model does not consider biomass-burning sources of the intercepted plumes, which, according to backward trajectory analyses, might have originated from Alaskan wildfires outside of the coarse $27 \mathrm{~km}$ domain.

On 21 July (Fig. 5), strong CO plumes from NYC urban emissions and biomass-burning were also measured by the research aircraft. The measured NYC urban plumes were aged, and intercepted over the North Atlantic Ocean about $600 \mathrm{~km}$ downwind of New York City between 14:30 UTC and 15:30 UTC as well as 19:00 UTC and 20:00 UTC at about $0.3 \mathrm{~km}$ altitude (Fig. 5a and b). The measured $\mathrm{CO}$ mixing ratios reached a maximum of about $350 \mathrm{ppbv}$, which is comparable to the levels observed in urban plumes near New York City on 20 July. The WRF-Chem model simulates the $\mathrm{CO}$ enhancement in association with the observed urban plumes, but it underestimates peak $\mathrm{CO}$ mixing ratios by about $100 \mathrm{ppbv}$. The simulated $\mathrm{CO}$ mixing ratio averaged along the flight track is about 20 ppbv lower than the observations (Fig. 5b), similar to 20 July. BB plumes were also intercepted by the aircraft, over Cape Cod at about $3 \mathrm{~km}$ altitude around 20:00 UTC on 21 July. These measured BB plumes are not reproduced by the model for the same reasons discussed for 20 July (Fig. 5a and b).

Figure 6 shows vertical distributions of chemical species $\left(\mathrm{CO}, \mathrm{O}_{3}, \mathrm{NO}_{\mathrm{y}}\right.$, and $\mathrm{HNO}_{3}$ ), ratios of chemical species $\left(\mathrm{CO} / \mathrm{NO}_{\mathrm{y}}, \mathrm{NO}_{\mathrm{x}} / \mathrm{NO}_{\mathrm{y}}\right.$, and $\left.\mathrm{O}_{3} / \mathrm{CO}\right)$, and meteorological fields (potential temperature, water vapor mixing ratio, and wind 
(a)
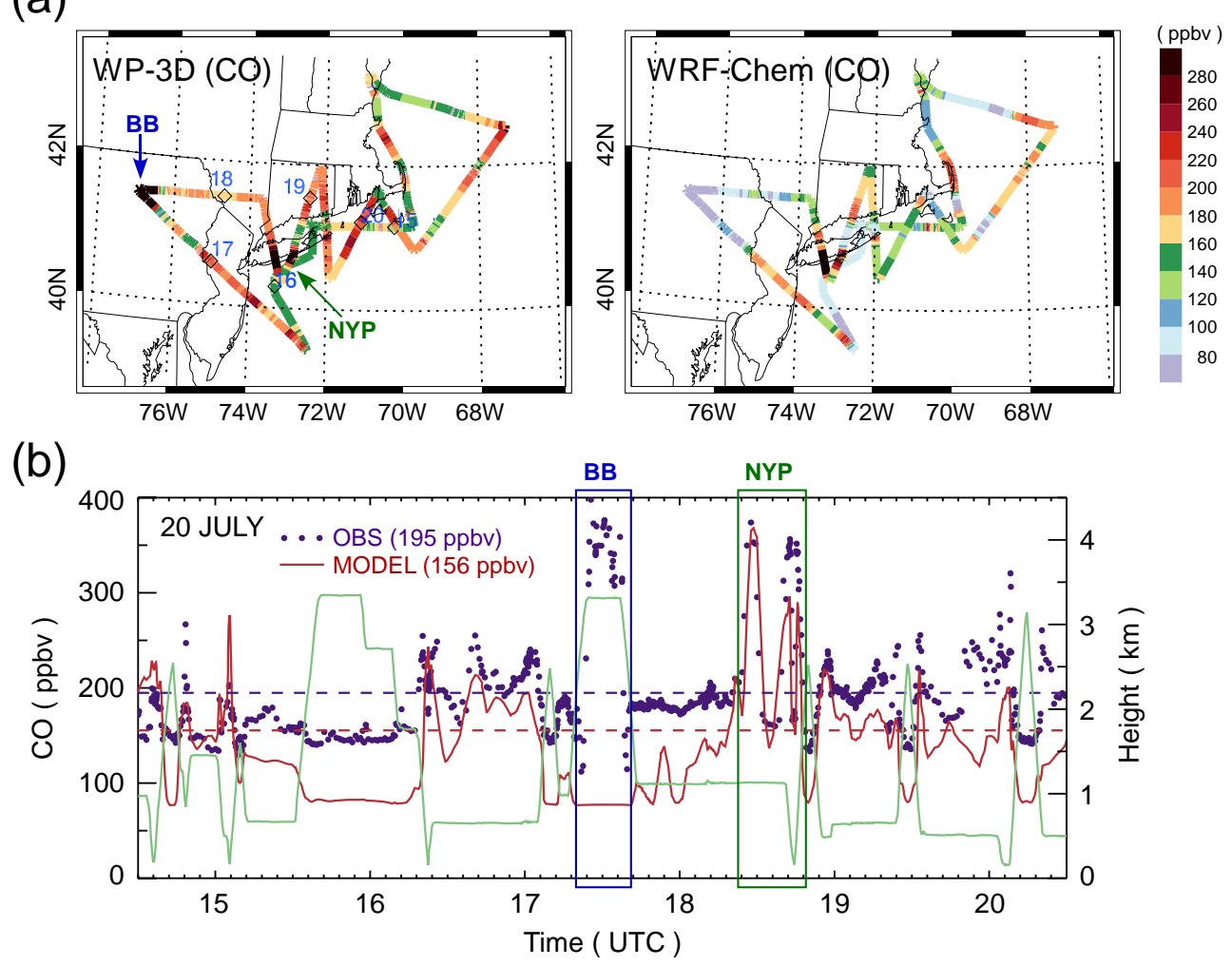

Fig. 4. (a) Observed and simulated CO mixing ratios along the WP-3D flight track on 20 July. Times of aircraft measurement are depicted. (b) Comparison of observed (dot) and simulated (red line) CO mixing ratios on 20 July as a function of time. "NYP" and "BB" in the figures indicate New York City urban plumes and biomass-burning plumes. Green solid line denotes the aircraft altitude. Dashed lines and values in (b) indicate mean mixing ratios below $1.5 \mathrm{~km}$ in observation and simulation, respectively.

direction and speed) in the NYC urban plume intercepted in the ascending ("spiral") track of the WP-3D around 18:45 UTC on 20 July (shown in Fig. 4b). The spiral was conducted along a vertically slanted path starting above the ocean and Long Island. A strong urban plume layer is well defined in the vertical profiles, starting from about $0.5 \mathrm{~km}$ up to $1.5 \mathrm{~km}$ (shaded in Fig. 6) with a mixed layer height of about $1.8 \mathrm{~km}$. The steep gradient seen at about $0.5 \mathrm{~km}$ in the profiles indicates that the urban plume is decoupled from the ocean surface (Fig. 6a). Relatively homogeneous profiles in the measured chemical species ratios above the $0.5 \mathrm{~km}$ level also suggest the air mass originated from the same pollutant sources in the NYC area (Fig. 6b). Local maxima of CO ( $\sim 350$ ppbv), $\mathrm{NO}_{\mathrm{y}}(\sim 35 \mathrm{ppbv})$, and $\mathrm{HNO}_{3}(\sim 20 \mathrm{ppbv})$ are found at a relatively low level of $0.4-0.5 \mathrm{~km}$, while higher $\mathrm{O}_{3}$ mixing ratios of about $100 \mathrm{ppbv}$ are found in the level of $0.8-1 \mathrm{~km}$ (Fig. 6a). In this urban plume $\mathrm{HNO}_{3}$ is a major oxidation product, accounting for $50-60 \%$ of $\mathrm{NO}_{\mathrm{y}}$. The ratio $\mathrm{NO}_{\mathrm{x}} / \mathrm{NO}_{\mathrm{y}}$ ranges between 0.3 and 0.4 in the plume layer, indicating relatively recent transport from the NYC metropoli$\tan$ area (Fig. 6b).

The formation of the vertically decoupled plume structure described above is associated with meteorological conditions
(Fig. 6c). The atmosphere was stably stratified with a vertical gradient of potential temperature over $10 \mathrm{~K} \mathrm{~km}^{-1}$ in the daytime lower atmosphere below $0.5 \mathrm{~km}$ over the ocean. Winds gradually changed with height from southwesterly flow of about $8 \mathrm{~m} \mathrm{~s}^{-1}$ near the surface to westerly flow of $4 \mathrm{~m} \mathrm{~s}^{-1}$ at about $1 \mathrm{~km}$. In general, as thermal atmospheric stability increases relative to wind shear, the gradient Richardson number, defined as the ratio of buoyancy production to the vertical shear production, increases, and consequently turbulence is suppressed and eventually collapses. This condition results in a decoupling of the air from the surface in terms of turbulence exchange, as shown by the observations over the MBL. NYC urban plumes extended vertically by convective turbulent mixing were transported over the stable MBL, consequently forming the strong decoupled plume structure in the coastal areas. The WRF-Chem model captures the vertically decoupled plume structures in chemical species' mixing ratios and their ratios shown in the observed NYC urban plume. The reasonable reproduction of the characteristic vertical structures in observations may be largely attributed to the fact that the simulated meteorology compares well to the observed thermal stability and wind shear (Fig. 6c). The model-simulated mixing ratios are underestimated in the 
(a)
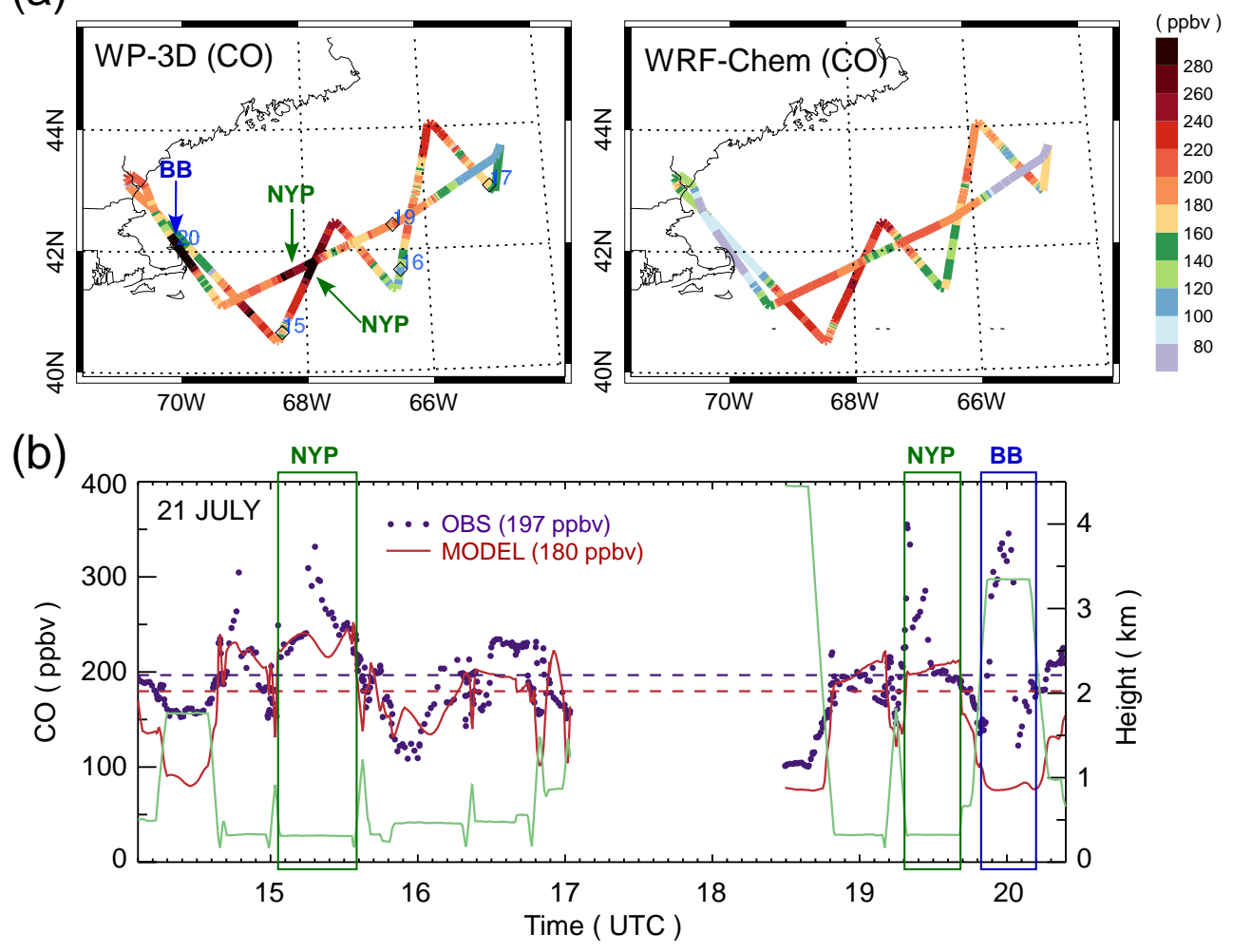

Fig. 5. (a) Observed and simulated CO mixing ratios along the WP-3D flight track on 21 July. Times of aircraft measurement are depicted. (b) Comparison of observed (dot) and simulated (red line) CO mixing ratios on 21 July as a function of time. "NYP" and "BB" indicate New York City urban plumes and biomass-burning plumes. Green solid line denotes the aircraft altitude. Dashed lines and values in (b) indicate mean mixing ratios below $1.5 \mathrm{~km}$ in observation and simulation, respectively. The WP-3D was located outside of the model domain for the missing period from 17:00 to 18:30 UTC.

strong plume layer (Fig. 6a). The bias in the simulated $\mathrm{NO}_{\mathrm{y}}$ $\left(=\mathrm{NO}+\mathrm{NO}_{2}+\mathrm{NO}_{3}+\mathrm{HNO}_{3}+\mathrm{HONO}+\mathrm{HNO}_{4}+\mathrm{N}_{2} \mathrm{O}_{5}\right.$ + PANs + organic nitrates) is largely attributed to underestimation of the $\mathrm{HNO}_{3}$ mixing ratios (5-10 ppbv) by the model. The $\mathrm{CO}$ and $\mathrm{O}_{3}$ mixing ratios compare better with observations by increasing their background levels when chemical IC/BCs in the simulation WRF60k (dashed line in Fig. 6a) are implemented, while the simulated $\mathrm{NO}_{\mathrm{y}}$ and $\mathrm{HNO}_{3}$ are marginally enhanced.

\subsubsection{Ozone plumes in the DC-3 lidar measurements and simulation}

The airborne lidar instrument on the NOAA DC-3 aircraft measured the 3-dimensional ozone distribution near New York City (20 July) and over the North Atlantic Ocean (21 July), allowing the vertical profiles of ozone plumes to be characterized in detail under different meteorological conditions. In addition, the comparison of ozone plumes measured near the New York City source area and in the far downwind region can demonstrate the evolution of ozone plumes during transport over the North Atlantic Ocean.
Figure 7 shows horizontal and vertical distributions of the observed and simulated ozone mixing ratios on 20 July. The DC-3 aircraft captured several strong ozone plumes just downwind of New York City between 21:30 UTC and 00:00 UTC (Fig. 7a), clearly showing the vertical distribution of ozone in the plumes (Fig. 7b). Maximum mixing ratios of ozone in the plumes ranged from 100 to $130 \mathrm{ppbv}$. The measured NYC ozone plumes reached an altitude of $1.5-2 \mathrm{~km}$, following the development of the daytime convective boundary layer (CBL) over land. The plume heights over land were higher by $500-1000 \mathrm{~m}$ than those of the plumes captured over the Gulf of Maine between 19:00 UTC and 20:00 UTC and over the ocean between 00:30 UTC and 01:00 UTC, indicating that the plume heights decrease according to transition from a CBL regime to a stable MBL regime. The WRF-Chem model reproduces the region with high ozone levels near New York City, but it underestimates the observed ozone levels (Fig. 7a). The vertical structures of the simulated NYC ozone plumes are qualitatively similar to the observations. However, the simulated ozone mixing ratio in the strong plume layer is lower by $10-20$ ppbv than the observations. The discrepancy in modeled and observed ozone 
(a)

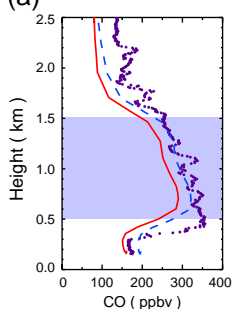

(b)

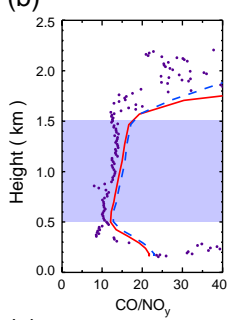

(c)
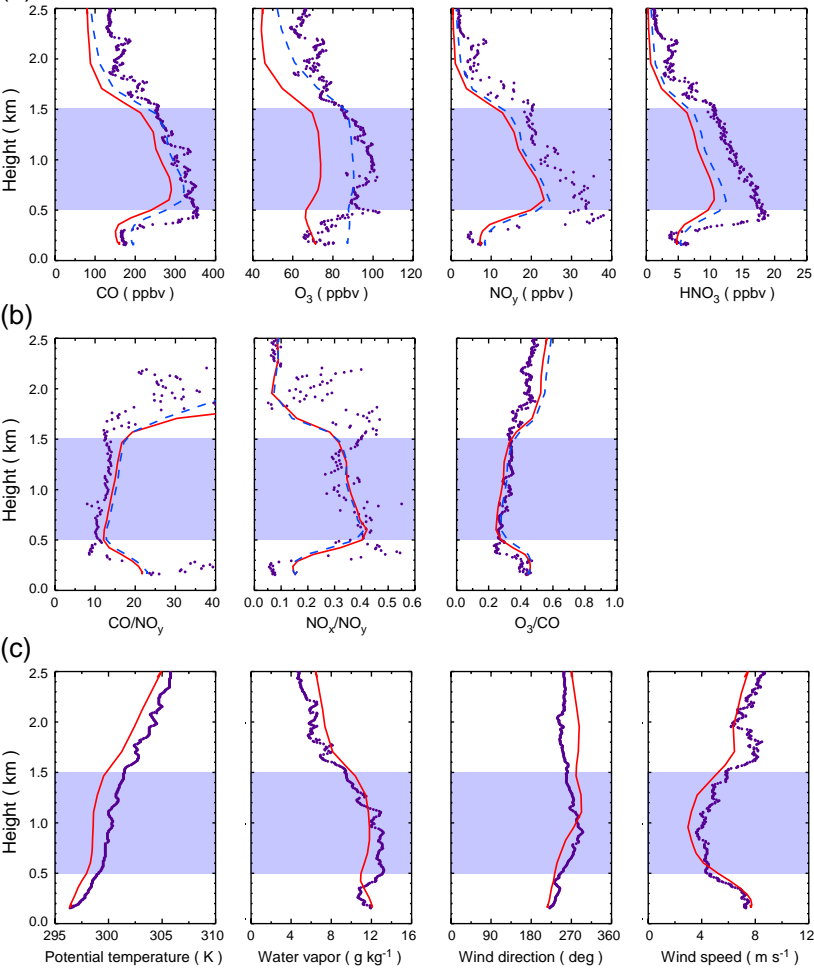

Fig. 6. Observed (dots purple line) and simulated (solid red and dashed blue lines) vertical distributions of (a) chemical species ( $\mathrm{CO}$, $\mathrm{O}_{3}, \mathrm{NO}_{\mathrm{y}}$, and $\left.\mathrm{HNO}_{3}\right)$, (b) ratios of chemical species $\left(\mathrm{CO} / \mathrm{NO}_{\mathrm{y}}\right.$, $\mathrm{NO}_{\mathrm{x}} / \mathrm{NO}_{\mathrm{y}}$, and $\mathrm{O}_{3} / \mathrm{CO}$ ), and (c) meteorological fields (potential temperature, water vapor mixing ratio, and wind speed and direction) in the NYC urban plume intercepted in the ascending track of the NOAA WP-3D aircraft around 18:45 UTC on 20 July. A strong NYC urban plume layer from $0.5 \mathrm{~km}$ to $1.5 \mathrm{~km}$ is shaded. Dashed lines in (a) and (b) show results from the simulation with chemical initial and boundary conditions including North American anthropogenic and biogenic emissions ("WRF60k").

mixing ratios is greater above the mixed-layer height. The simulated ozone plumes are wider than the observed ones. Figure $7 \mathrm{c}$ shows the observed and simulated vertical distributions of a selected ozone plume around 23:15 UTC (denoted by the double-headed arrow in Fig. 7a and dashed lines in Fig. 7b). Except for ozone differences mainly caused by background levels, the observed and simulated ozone plumes are similar in vertical structure, showing a vertically decoupled ozone plume structure. This characteristic feature is similar to the ozone vertical structure in the NYC urban plumes captured by the WP-3D on 20 July (Fig. 6a).

Figure 8 shows horizontal and vertical distributions of the observed and simulated ozone mixing ratios on 21 July after the NYC ozone plumes had been transported for one day. The aircraft encountered strong ozone plumes near Boston and over the North Atlantic Ocean. The location of ozone plumes (Fig. 8a) over the North Atlantic Ocean was close to the position $\left(\sim 68.0^{\circ} \mathrm{W}\right.$ and $41.5^{\circ} \mathrm{N}$ in Fig. 5) of $\mathrm{CO}$ plumes measured by the WP-3D aircraft on that day. The ozone plumes had a vertically decoupled structure as well as high ozone levels of 100-130 ppbv in the strong plume layers (Fig. 8b). The ozone plume heights ranged $1-1.5 \mathrm{~km}$, which are lower than that of the ozone plumes measured near New York City on the previous day. This finding implies that the ozone plumes were efficiently transported in the lower atmosphere over the North Atlantic Ocean without significant influence of $\mathrm{O}_{3}$ loss processes. An efficient transport mechanism and photochemical evolution of a strong NYC urban plume will be explained in detail in Sect. 4.3. The simulated ozone plumes compared well with the observations in terms of the plume positions and their typical vertical structure (Fig. 8a and b). The ozone vertical distribution in an observed plume around 22:30 UTC (denoted by the doubleheaded arrow in Fig. 8a and dashed lines in Fig. 8b) shows clearly enhanced ozone plume layers (over $100 \mathrm{ppbv}$ ) above the ocean surface with the height of maximum $\mathrm{O}_{3}$ at around $0.3-0.5 \mathrm{~km}$ (Fig. 8c). The WRF-Chem model reproduces the vertical decoupled structure of the ozone plume in the layer below $1.5 \mathrm{~km}$. However, the model systematically underestimates the ozone mixing ratios above $1.5 \mathrm{~km}$ by $10-20 \mathrm{ppbv}$, as on 20 July.

\subsection{Transport and chemical transformation of ozone plumes}

The WP-3D and DC-3 aircraft measurements on 20 and 21 July clearly characterized the NYC urban plumes in the nearsource area and far downwind region horizontally and vertically. The WRF-Chem model reproduced the characteristics of the NYC urban plumes reasonably well, including plume location and typical vertical structure. Based on the successful simulations of meteorology and plume transport, ozone evolution, source identification, and transport and chemical transformation processes are examined further.

Figure 9 shows horizontal distributions of the simulated $\mathrm{O}_{3}$ mixing ratios with horizontal wind fields from 15:00 UTC on 20 July to 00:00 UTC on 22 July at 3-h intervals. The ozone mixing ratios and horizontal winds are vertically averaged from near the surface to about $1700 \mathrm{~m}$. The ozone level near New York City is relatively low at 15:00 UTC (10:00 local standard time) on 20 July when photochemical reactions are relatively slow (Fig. 9a). At this time, weak ozone plumes ( $70 \mathrm{ppbv})$, exported from the NYC metropolitan area on the previous day, are located in the Gulf of Maine, and transported by southwesterly winds. At 18:00 UTC the ozone begins to increase in the Washington-Boston urban corridor along the East Coast of the US with enhanced photochemical ozone production (Fig. 9b). Strong ozone plumes over 90 ppbv appear near New York City, and move eastward (Fig. 9c and d). This is the time period (21:00-24:00 UTC) that the DC-3 aircraft captured several strong ozone plumes near New York City (Fig. 7). The ozone plumes over the 
(a)

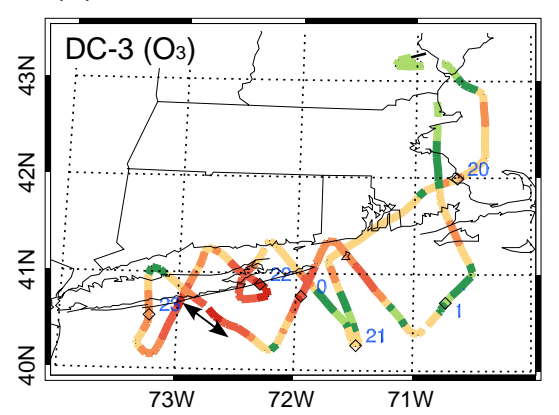

(b)
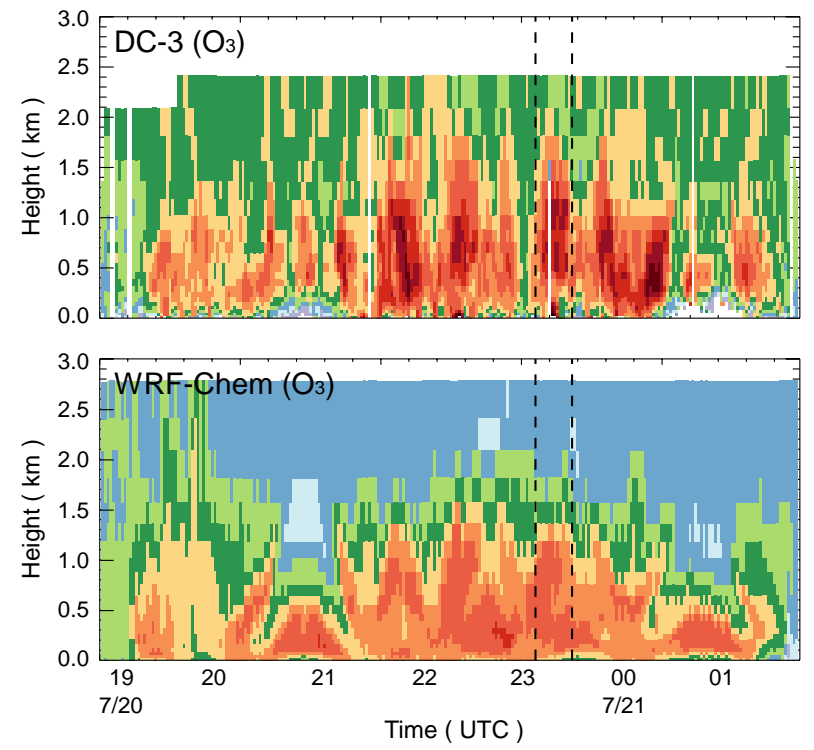

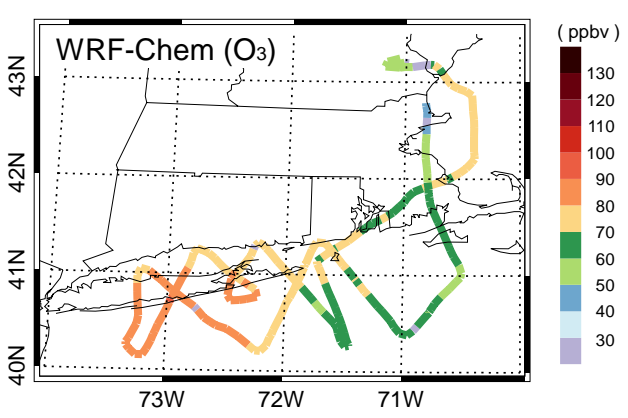

(c)

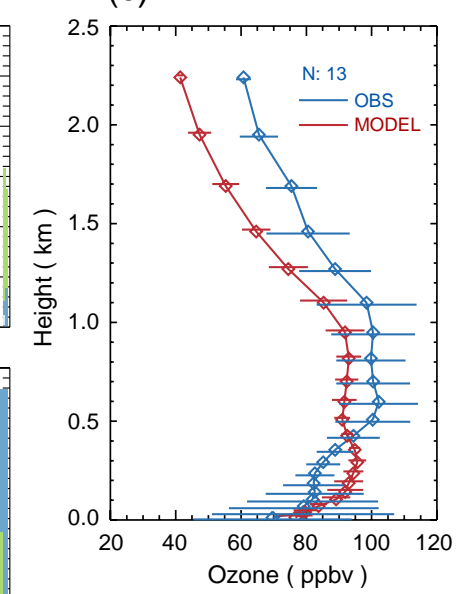

Fig. 7. (a) Horizontal distributions of observed and simulated $\mathrm{O}_{3}$ mixing ratios measured from the DC-3 aircraft on 20 July. The ozone mixing ratios are vertically averaged from near surface to about $1.5 \mathrm{~km}$. (b) Vertical distributions of observed (top) and simulated (bottom) $\mathrm{O}_{3}$ mixing ratios on 20 July as a function of time. (c) Mean profiles and standard deviations of observed and simulated $\mathrm{O}_{3}$ mixing ratios in an ozone plume denoted by the double-headed arrow in (a) and dashed lines in (b). $N$ denotes the number of vertical soundings.

Gulf of Maine are enhanced in their mixing ratios by photochemical production during the transport over the North Atlantic Ocean in the same period (Fig. 9b-d). During the nighttime on 21 July (Fig. 9e-h), the detached NYC ozone plumes move eastward, keeping ozone levels of $70-80 \mathrm{ppbv}$ in the plumes unaltered, and form an elongated band of enhanced ozone from the southwest to northeast. Meanwhile, the ozone levels over New York City rapidly decrease mainly due to titration, and the ozone plumes that were over the Gulf of Maine at 15:00 UTC on 20 July move out to Nova Scotia.

As photochemical reactions begin again on 21 July (Fig. 9i-1), ozone levels increase in the urban area. In addition, in the band of ozone plumes formed over the North Atlantic Ocean the ozone level persists during the daytime. This time period corresponds to when the WP-3D and DC-3 aircraft intercepted strong ozone plumes on 21 July (Figs. 5 and 8 ). The persistent westerly or northwesterly winds from land and southerly or southwesterly winds over the ocean generate the convergence zone over the North Atlantic Ocean, leading to the band of strong ozone plumes.

To identify sources and investigate the photochemical evolution in the observed NYC ozone plumes, we conducted a simulation with doubled CO emissions for the NYC area. The contribution of the increased NYC source in the urban plumes can be represented by the difference of the $\mathrm{CO}$ mixing ratios between the simulation with doubled $\mathrm{CO}$ emissions and the control simulation. Here the $\mathrm{CO}$ contribution of the NYC source is specifically named $\mathrm{CO}^{\mathrm{NYC}}$. The vertically extended NYC plume in the CBL (Fig. 6) is separated into a lower atmospheric layer from $\sim 140 \mathrm{~m}$ to $\sim 600 \mathrm{~m}$ and an upper atmospheric layer from $\sim 600 \mathrm{~m} \sim 1300 \mathrm{~m}$. The lower atmospheric layer corresponds to the strong urban plume layer observed by the WP-3D and DC-3 aircraft on 21 July (Figs. 5 and 8). 
(a)

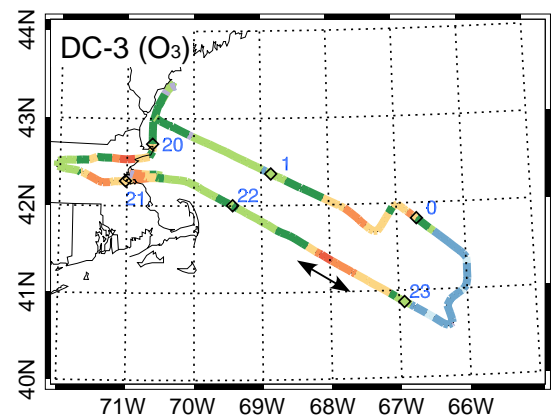

(b)
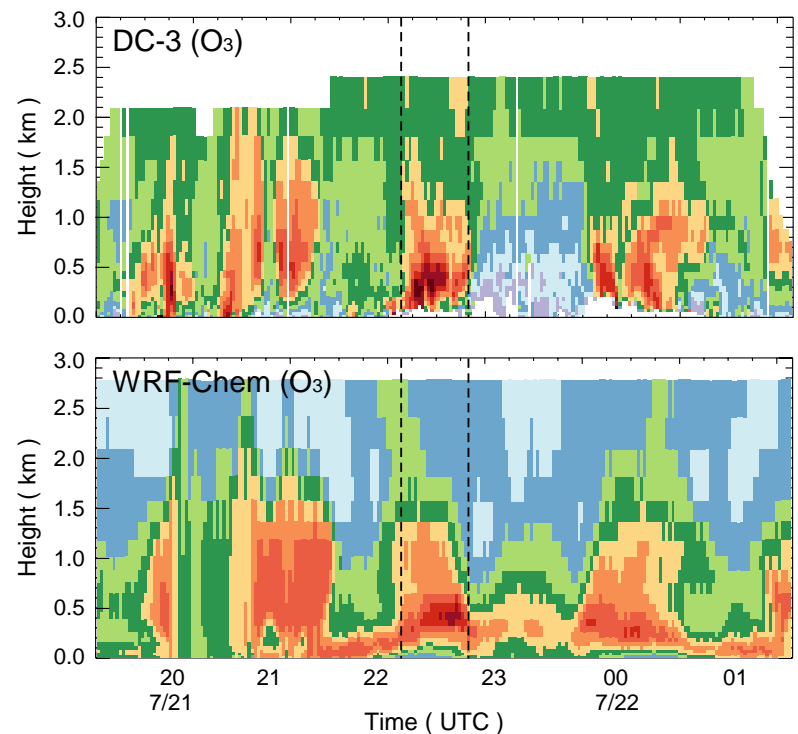

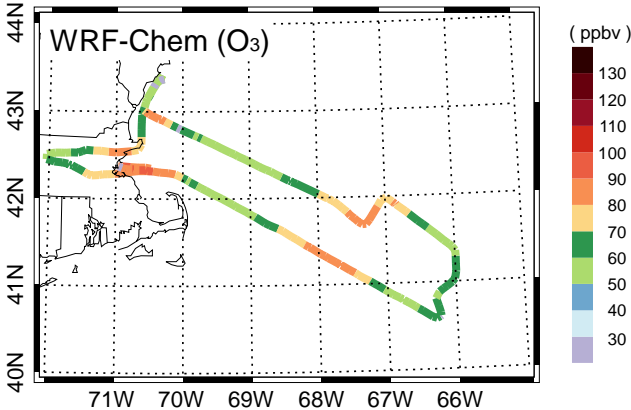

(c)

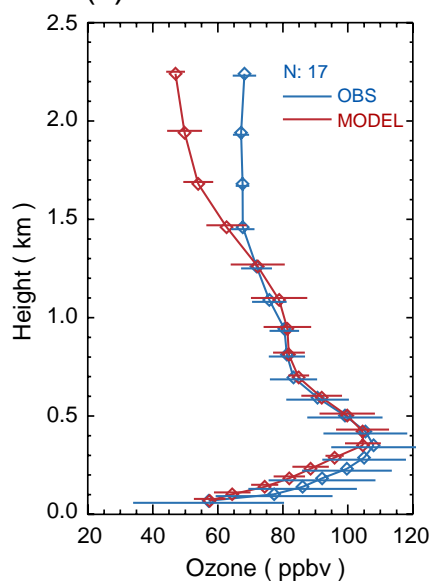

Fig. 8. (a) Horizontal distributions of observed and simulated $\mathrm{O}_{3}$ mixing ratios measured from the DC-3 aircraft on 21 July. The ozone mixing ratios are vertically averaged from near surface to about $1.5 \mathrm{~km}$. (b) Vertical distributions of observed (top) and simulated (bottom) $\mathrm{O}_{3}$ mixing ratios on 21 July as a function of time. (c) Mean profiles and standard deviations of observed and simulated $\mathrm{O}_{3}$ mixing ratios in an ozone plume denoted by the double-headed arrow in (a) and dashed lines in (b).

Figure 10 shows horizontal distributions of the simulated $\mathrm{CO}^{\mathrm{NYC}}$ mixing ratios vertically averaged from $\sim 140 \mathrm{~m}$ to $\sim 600 \mathrm{~m}$, starting from 15:00 UTC on 20 July to 00:00 UTC on 22 July with a 3-h time interval. During the daytime on 20 July, plumes of high $\mathrm{CO}^{\mathrm{NYC}}$ in the lower atmospheric layer appear near New York City due to strong emissions in the urban area, and extend toward Cape Cod by southwesterly winds (Fig. 10a-d). The extended NYC plumes detach from New York City by northerly and northwesterly winds during the nighttime on 21 July (Fig. 10e-h). The NYC source forms a band of $\mathrm{CO}^{\mathrm{NYC}}$ plumes over the North Atlantic Ocean. This $\mathrm{CO}^{\mathrm{NYC}}$ band persists through the daytime on 21 July (Fig. 10i-1). The forward trajectory of a $\mathrm{CO}^{\mathrm{NYC}}$ plume started at 18:00 UTC on 20 July was calculated to identify the source of measured urban plumes on 21 July by the research aircraft (Figs. 5 and 8). The column of the lower plume layer was tracked following the column-averaged wind fields. The plume location at each time is shown in Fig. 10c-1 and the full trajectory of the $\mathrm{CO}^{\mathrm{NYC}}$ plume from 18:00 UTC on 20 July to 00:00 UTC on 22 July is shown in Fig. 10a. The NYC source in the lower layer was transported northeastward over land, and then moved over the ocean near Cape Cod. These results confirm that the urban plumes measured over the North Atlantic Ocean by the research aircraft on 21 July originated near New York City on 20 July. On the other hand, it is clearly seen that strong $\mathrm{CO}^{\mathrm{NYC}}$ plumes in the Gulf of Maine, which originated from New York City on the previous day, are transported to Nova Scotia without significant change in mixing ratio (Fig. 10a-f), and were intercepted by the WP-3D on 21 July (not shown).

Figure 11 shows horizontal distributions of the simulated $\mathrm{CO}^{\mathrm{NYC}}$ mixing ratios vertically averaged from $\sim 600 \mathrm{~m}$ $\sim 1300 \mathrm{~m}$, starting from 15:00 UTC on 20 July to 00:00 UTC on 22 July with a 3 -h time interval. The $\mathrm{CO}^{\mathrm{NYC}}$ plume above New York City is enhanced as the CBL develops during the daytime on 20 July (Fig. 11a-d). These $\mathrm{CO}^{\text {NYC }}$ plumes are 

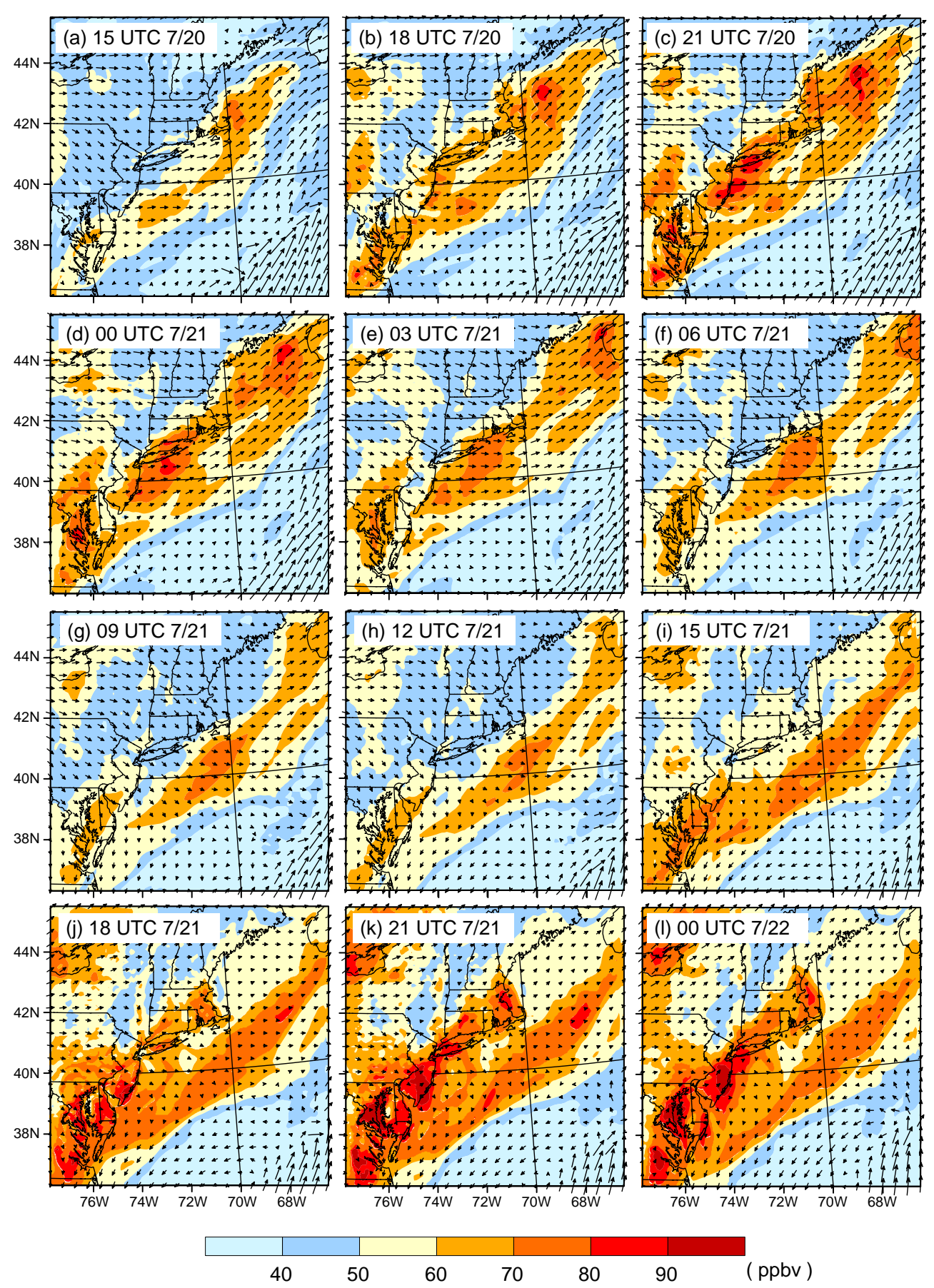

Fig. 9. Horizontal distributions of simulated $\mathrm{O}_{3}$ mixing ratios and horizontal wind fields from 15:00 UTC on 20 July to 00:00 UTC on 22 July with 3-h intervals. The ozone mixing ratios and horizontal wind fields are vertically averaged from near surface to about $1700 \mathrm{~m}$.

detached from Long Island and transported over the ocean during the nighttime on 21 July (Fig. 11e-h), and elongate in the confluent flow region (Fig. 11i-1). During the transport of the plumes, their $\mathrm{CO}^{\mathrm{NYC}}$ mixing ratios are almost unaltered. In addition, the upper part of the $\mathrm{CO}^{\mathrm{NYC}}$ plume initiated at 18:00 UTC on 20 July has a much different trajectory (shown in Fig. 11a) compared to the lower part of the plume
(Fig. 10a), indicating that the pollutants were transported in layers. These analyses clearly show that the transport pattern of the NYC plume is subject to meteorology, consequently altering the downwind region of influence.

The low-level atmospheric transport mechanism over the North Atlantic Ocean and photochemical evolution in the urban plumes during the transport are investigated using the 

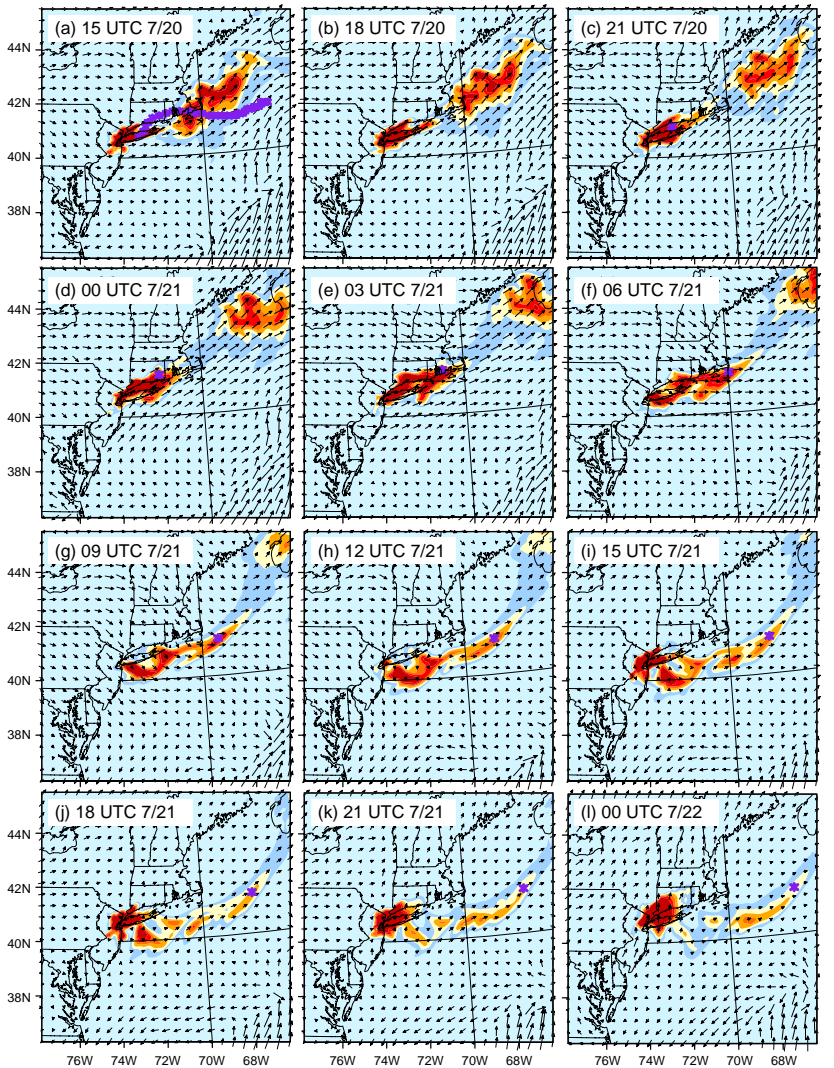

10

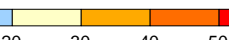

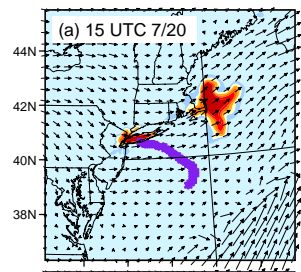
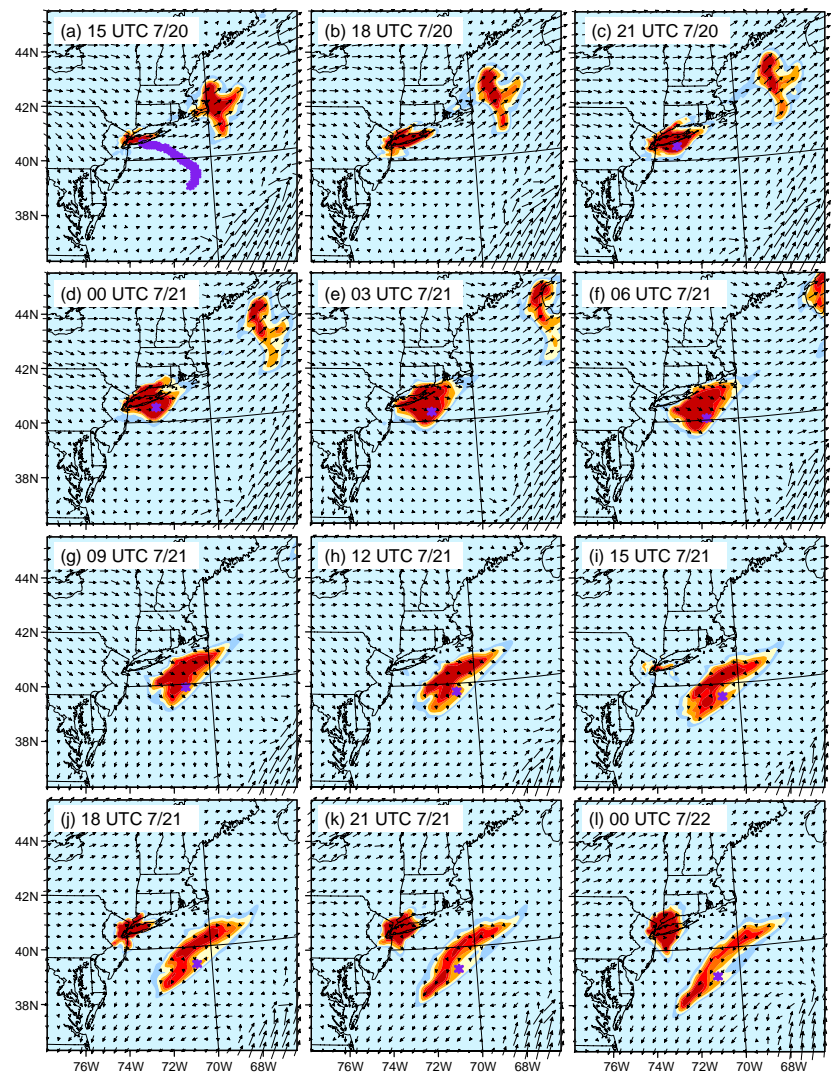

\begin{tabular}{rr|rrrrr|r}
1 & & & & & $\mid$ & \\
10 & 20 & 30 & 40 & 50 & 60 & (ppbv)
\end{tabular}

Fig. 11. Horizontal distributions of simulated $\mathrm{CO}^{\mathrm{NYC}}$ mixing ratios and horizontal wind fields in the upper-level NYC plume layer from 15:00 UTC on 20 July to 00:00 UTC on 22 July with 3-h intervals. The plotted $\mathrm{CO}^{\mathrm{NYC}}$ mixing ratios are the difference between simulation with doubled $\mathrm{CO}$ emissions of the New York City area and control simulation, and vertically averaged from $\sim 600 \mathrm{~m}$ to $\sim 1300$ $\mathrm{m}$. The full forward trajectory of an urban $\mathrm{CO}$ plume originated from New York City from 18:00 UTC on 20 July to 00:00 UTC on 22 July is shown in (a), and the location of the plume tracked is depicted by asterisk marks in (c-l).

creases over land during the nighttime (00:00-05:00 UTC), the plumes are decoupled from the surface, and transported over the nocturnal stable boundary layer. During the nocturnal transport over land, the lower plume layer maintains $\mathrm{O}_{3}$ levels of 80-90 ppbv. The increase of $\mathrm{NO}_{\mathrm{x}} / \mathrm{NO}_{\mathrm{y}}$ from 0.2 to 0.4 in the plume layer indicates that nocturnal anthropogenic emissions from the Cape Cod region partly contribute to the NYC plumes. After 06:00 UTC on 21 July when the transport of the lower plumes occurs over the North Atlantic Ocean, the plume layer can be clearly defined regardless of time of day. This is mainly attributed to a stably stratified atmosphere (Fig. 12d) that significantly limits surface deposition. The vertical gradients of potential temperature for the layer between $0.1-0.3 \mathrm{~km}$ were about $30 \mathrm{~K} \mathrm{~km}^{-1}$ over the North Atlantic Ocean (point 1: $67.30^{\circ} \mathrm{W}, 41.05^{\circ} \mathrm{N}$, 
(a)

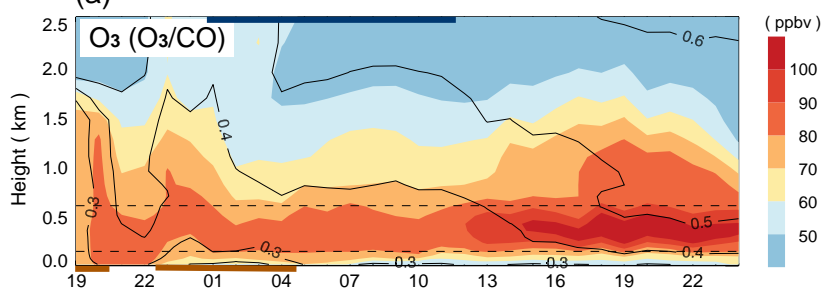

(b)

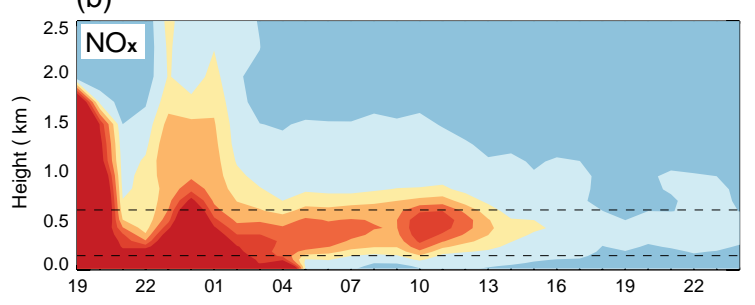

(c)

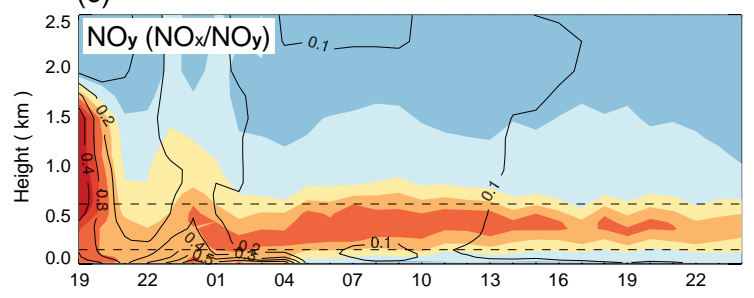

(d)

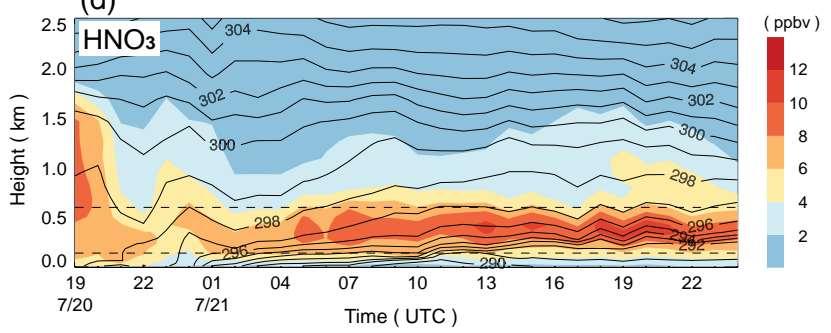

Fig. 12. Time-height plots of simulated (a) $\mathrm{O}_{3}$ and $\mathrm{O}_{3} / \mathrm{CO}$, (b) $\mathrm{NO}_{x}$, (c) $\mathrm{NO}_{\mathrm{y}}$ and $\mathrm{NO}_{\mathrm{x}} / \mathrm{NO}_{\mathrm{y}}$, and (d) $\mathrm{HNO}_{3}$ and potential temperature along the forward trajectory of the lower-level NYC plumes (dashed lines) denoted in Fig. 10. Upper and lower thick lines in (a) denote nighttime period and transport over land, respectively.

22:55 UTC and point 2: $67.04^{\circ} \mathrm{W}, 41.98^{\circ} \mathrm{N}, 24: 10 \mathrm{UTC}$ ) measured by drop-sondes from the DC-3 aircraft on 21 July (not shown). The $\mathrm{NO}_{\mathrm{x}}$ levels of the plume layer, which are largely maintained by transport of anthropogenic emissions, remain at about $2 \mathrm{ppbv}$ in the nocturnal transport over the stable MBL between 06:00 UTC and 12:00 UTC on 21 July, while the $\mathrm{O}_{3}$ mixing ratios are $80-90$ ppbv. Thermal decomposition of PANs slightly increases the $\mathrm{NO}_{\mathrm{x}}$ levels around 10:00-12:00 UTC. As photochemical reactions begin again (after 13:00 UTC on 21 July), $\mathrm{NO}_{\mathrm{x}}$ oxidation results in a rapid decrease of the $\mathrm{NO}_{\mathrm{x}}$ level down to $0.4-0.8 \mathrm{ppbv}$ and an increase of the $\mathrm{O}_{3}$ level to over $100 \mathrm{ppbv}$. During the transport over the MBL occurring along isentropic surfaces between $292^{\circ} \mathrm{K}$ and $297^{\circ} \mathrm{K}$, the $\mathrm{HNO}_{3}$ mixing ratios ranging between $6-10 \mathrm{ppbv}$ in the plume layer are maintained with (a)

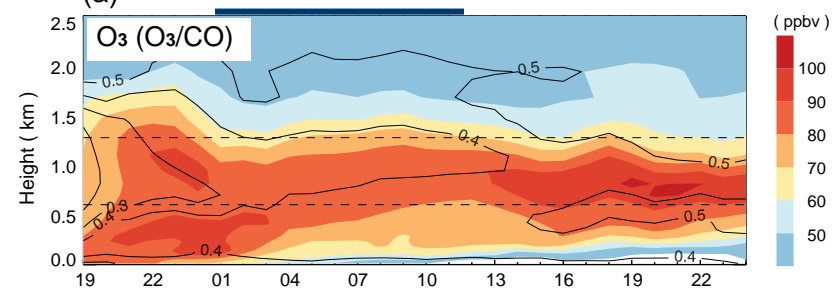

(b)

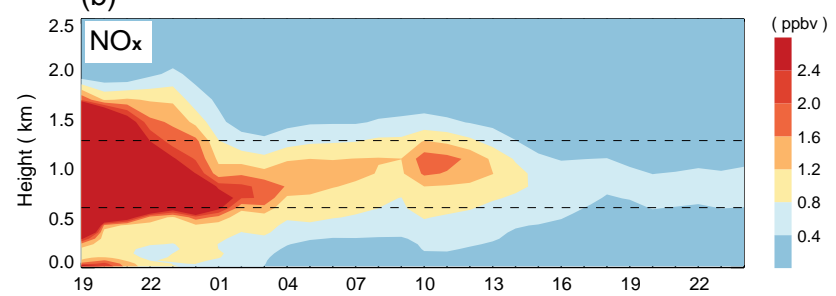

(c)

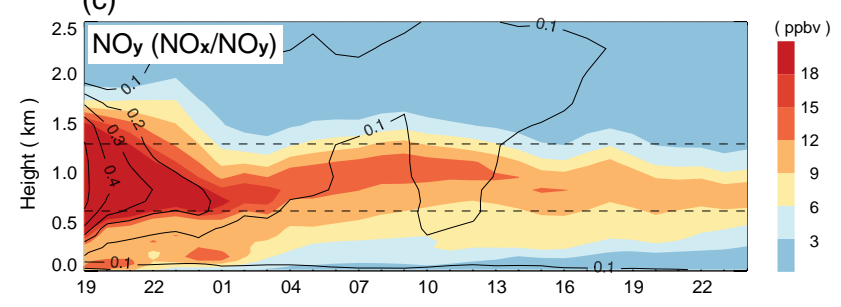

(d)

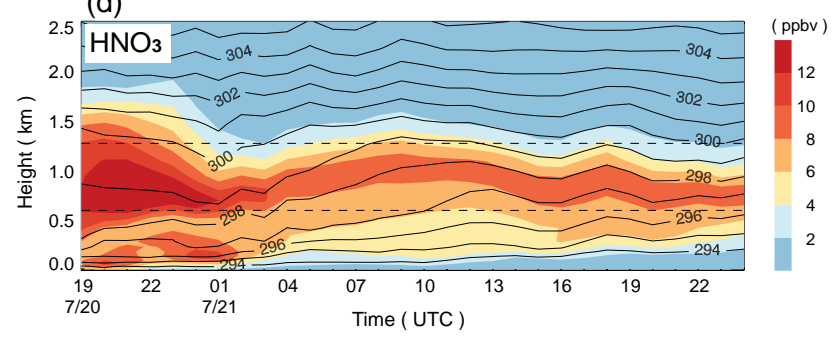

Fig. 13. Time-height plots of simulated (a) $\mathrm{O}_{3}$ and $\mathrm{O}_{3} / \mathrm{CO}$, (b) $\mathrm{NO}_{\mathrm{x}}$, (c) $\mathrm{NO}_{\mathrm{y}}$ and $\mathrm{NO}_{\mathrm{x}} / \mathrm{NO}_{\mathrm{y}}$, and (d) $\mathrm{HNO}_{3}$ and potential temperature along the forward trajectory of the upper-level NYC plumes (dashed lines) denoted in Fig. 11. Upper thick lines in (a) denote nighttime period. The upper-level NYC plumes were transported over the ocean during the full trajectory period.

slight increases when $\mathrm{NO}_{\mathrm{x}}$ is oxidized around 13:00 UTC on 21 July.

Figure 13 shows vertical distributions of $\mathrm{O}_{3}$ and $\mathrm{O}_{3} / \mathrm{CO}$, $\mathrm{NO}_{\mathrm{x}}, \mathrm{NO}_{\mathrm{y}}$ and $\mathrm{NO}_{\mathrm{x}} / \mathrm{NO}_{\mathrm{y}}$, and $\mathrm{HNO}_{3}$ and potential temperature along the forward trajectory of the upper-level NYC plumes denoted in Fig. 11. The upper part of the plumes is directly transported over the North Atlantic Ocean moving southeastward after leaving the NYC metropolitan area (Fig. 11a). The characteristics of photochemical evolution in the upper-level NYC plume layer are quite similar to those in the lower-level NYC plume layer. The marine atmosphere is stably stratified during the transport period (Fig. 13d) even though the thermal stability is relatively weak compared to that in the lower plume layer trajectory. As the plume layer 


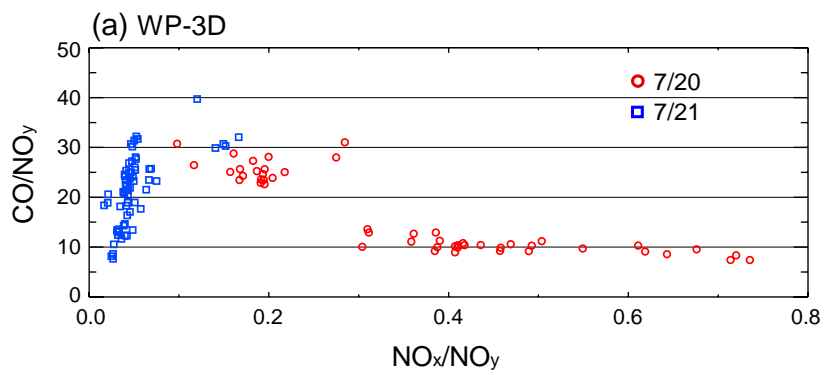

(b) WRF-Chem

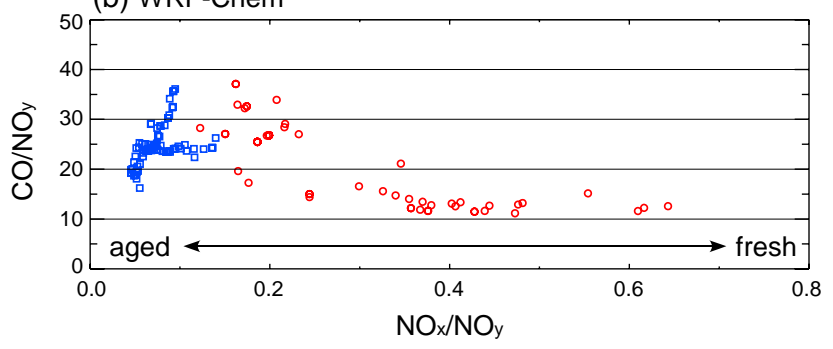

Fig. 14. $\mathrm{CO} / \mathrm{NO}_{\mathrm{y}}$ versus $\mathrm{NO}_{\mathrm{x}} / \mathrm{NO}_{\mathrm{y}}$ in (a) WP-3D measurements and (b) model simulation on 20 July (red open circles) and 21 July (blue open squares). Plume age is represented as a function of $\mathrm{NO}_{\mathrm{x}} / \mathrm{NO}_{\mathrm{y}}$ ratio.

moves farther from New York City, the vertically decoupled structure is clearly seen. During nocturnal transport between 01:00 UTC and 12:00 UTC on 21 July, the $\mathrm{O}_{3}$ mixing ratios in the plumes layer remain at $80-90$ ppbv. The $\mathrm{O}_{3}$ level then increases to over $100 \mathrm{ppbv}$ as a result of daytime $\mathrm{NO}_{\mathrm{x}}$ oxidation (after 13:00 UTC on 21 July). Similarly, $\mathrm{NO}_{\mathrm{x}}$ levels in the range $0.8-2.0 \mathrm{ppbv}$ in the plume layer are maintained during nocturnal transport, and then are rapidly reduced below 0.8 ppbv by daytime $\mathrm{NO}_{\mathrm{x}}$ oxidation, consequently enhancing $\mathrm{O}_{3}$ levels in the plume layer. As in the lower plume layer, the $\mathrm{HNO}_{3}$ in the upper plume layer is efficiently transported on isentropic surfaces over the North Atlantic Ocean in the 30-h plume trajectory while keeping its vertically decoupled plume structure.

Efficient low-level transport of the NYC plumes over the North Atlantic Ocean is achieved by advection of vertically well-mixed plumes from the continental CBL regime over the stable MBL where there is only sporadic turbulent mixing. During the transition from the convective to the stable regime, the plume height is reduced as a consequence of meteorological adjustment, namely the thermal internal boundary layer (19:00-01:00 UTC in Figs. 12 and 13). The mixing ratios of chemical species in the plumes above the shallow MBL $(\sim 100 \mathrm{~m})$ are maintained due to the lack of significant surface losses (after 05:00 on 21 July in Fig. 12), whereas pollutants within the MBL are more likely to be subject to deposition at the ocean surface, consequently reinforcing the vertically decoupled plume structure. This vertically decoupled plume structure can form over land in the day to night transition, which is seen at 01:00-03:00 UTC in Fig. 12.
The characteristics of transported reactive nitrogen species in the NYC urban plumes are further examined using the WP-3D measurements and WRF-Chem simulation. Here we define the NYC plumes by regions where $\mathrm{CO}$ mixing ratios are more than $10 \mathrm{ppbv}$ larger than the mean values for both the observations and simulations. We used data from 18:00-19:00 UTC on 20 July and 14:30-15:30 UTC and 18:40-19:40 UTC on 21 July, the periods corresponding to the NYC plume intercepts by the WP-3D (Figs. 4 and 5 ). The NYC urban plume positions in the observations and simulations are well matched. Figure 14 shows $\mathrm{CO} / \mathrm{NO}_{\mathrm{y}}$ ratios of the observed and simulated NYC plume intercepts on 20 and 21 July as a function of $\mathrm{NO}_{\mathrm{x}} / \mathrm{NO}_{\mathrm{y}}$. The $\mathrm{CO} / \mathrm{NO}_{\mathrm{y}}$ ratios in the NYC plumes ranged within 5-35 similarly on both days (Fig. 14a), suggesting that photochemically fresh $\left(\mathrm{NO}_{\mathrm{x}} / \mathrm{NO}_{\mathrm{y}}>0.4\right)$ plumes started near New York City on 20 July were efficiently transported over the North Atlantic Ocean. The WRF-Chem reproduces the observed behavior in $\mathrm{CO} / \mathrm{NO}_{\mathrm{y}}$ as a function of plume age (Fig. 14b) while showing a high correlation $(R=0.94)$ between the observed and simulated $\mathrm{NO}_{\mathrm{x}} / \mathrm{NO}_{\mathrm{y}}$. The good agreement between observation and model indicates that the model is properly accounting for the transport and aging processes in the NYC plumes.

\subsection{Sensitivity analyses}

\subsubsection{Impact of chemical IC/BCs on ozone levels}

Figure 15 shows observed and simulated $\mathrm{O}_{3}$ mixing ratios from the WP-3D flights on 20 and 21 July. The NYC urban plumes and biomass-burning plume intercepts denoted in Figs. 4 and 5 are indicated by the rectangles. The simulated meteorology is identical among all the simulations. All simulations with dynamic chemical IC/BCs increase the $\mathrm{O}_{3}$ level by enhancing the background levels on both the days compared to the control simulation. In the NYC urban plumes, the simulation with the North American anthropogenic/biogenic emissions (WRF60k) increases $\mathrm{O}_{3}$ mixing ratios by 10-20 ppbv. When the $\mathrm{BB}$ source is added to the simulation WRF60k (WRF60k_BB), the $\mathrm{O}_{3}$ mixing ratios only increase by a few ppbv. The simulation with MOZART-4 chemical IC/BCs and BB source (MOZART_BB) shows similar $\mathrm{O}_{3}$ levels as the simulation WRF60k_BB in the NYC plumes. On the other hand, the two simulations that include the BB source (WRF60k_BB and MOZART_BB) enhance $\mathrm{O}_{3}$ levels by $20-30 \mathrm{ppbv}$ in the observed $\mathrm{BB}$ plumes. These results affirm that the Alaskan wildfires as well as the North American anthropogenic/biogenic emissions influenced the northeast US, suggesting that proper chemical IC/BCs have a large impact on local air-quality simulations (e.g. Song et al., 2008; Tang et al., 2009).

Figure 16 shows the impacts of different chemical IC/BCs on the local ozone simulation, separated in terms of the MOZART-4, BB source, and the North American 
anthropogenic/biogenic emissions. Each chemical IC/BCs impact was calculated from the $\mathrm{O}_{3}$ mixing ratio difference between two simulations: "MOZART-4" = MOZART_BB WRF60k_BB, "BB source" = WRF60k_BB - WRF60k, and "NA emission" = WRF60k - control run. This analysis was done along the complete WP-3D flight tracks (Fig. 16a-c) and DC-3 flight tracks (Fig. 16d-f) conducted on 20 and 21 July. On average, the MOZART- 4 chemical IC/BCs enhance $\mathrm{O}_{3}$ levels by $6-8 \mathrm{ppbv}$ in the $1-3 \mathrm{~km}$ layer and by $2-3 \mathrm{ppbv}$ below $1 \mathrm{~km}$ (Fig. 16a and d). The impact of the BB source is similar to that of MOZART-4 in the averaged vertical distribution. For some portions of the flights around $2 \mathrm{~km}$, the BB source enhances the simulated $\mathrm{O}_{3}$ level by over $40 \mathrm{ppbv}$ (Fig. 16b and e). The impact of the North American anthropogenic/biogenic emissions is in the range of 4-12 ppbv $\mathrm{O}_{3}$ on average in the layer below $3 \mathrm{~km}$ (Fig. 16c and f), which is relatively larger than the average impacts of the MOZART-4 and BB source. As expected, the impact of the North American emissions is mainly confined within the CBL.

Figure 17 shows vertical distributions of the observed and simulated $\mathrm{O}_{3}$ mixing ratios on 20 and 21 July for the time and location of profiles by ozone-sondes launched from the NOAA R/V Ronald H. Brown. The simulated BB impact extends to over $8 \mathrm{~km}$ on both days. The BB impact throughout the profile on 21 July is larger than that on 20 July with a maximum enhancement of 40-50 ppbv around $2 \mathrm{~km}$, in accordance with the enhancements shown in Fig. 16b and e. All simulations significantly underestimate the upper layer (above $\sim 3 \mathrm{~km}$ ) $\mathrm{O}_{3}$ levels except for the simulation using the MOZART_BB chemical IC/BCs.

\subsubsection{Impact of chemical IC/BCs on surface ozone levels}

Ozone data from twenty surface monitoring stations near New York City $\left(75.0^{\circ} \mathrm{W}-73.0^{\circ} \mathrm{W}, 40.4^{\circ} \mathrm{N}-42.0^{\circ} \mathrm{N}\right)$ are compared to the simulated $\mathrm{O}_{3}$ mixing ratio to investigate the impact of chemical IC/BCs on surface $\mathrm{O}_{3}$ levels. Figure 18 shows diurnal variations of the observed and simulated $\mathrm{O}_{3}$ mixing ratios averaged for the 13 urban stations and 7 nonurban stations, respectively. The observed average $\mathrm{O}_{3}$ levels range from $10 \mathrm{ppbv}$ during the nighttime to about $80 \mathrm{ppbv}$ during the daytime in the urban stations (Fig. 18a) while ranging from $15-20 \mathrm{ppbv}$ to $75 \mathrm{ppbv}$ during the diurnal cycle in the non-urban stations (Fig. 18b). The control simulation reproduces the diurnal variation of the observed surface ozone reasonably well for both the urban $(R=0.92)$ and non-urban $(R=0.91)$ stations. However, the model underestimates the observed daytime peak $\mathrm{O}_{3}$ mixing ratios by about $10 \mathrm{ppbv}$, and overestimates nocturnal $\mathrm{O}_{3}$ levels by up to $15 \mathrm{ppbv}$.

The implementation of chemical IC/BCs leads to a relatively significant impact on the surface ozone by increasing the background $\mathrm{O}_{3}$ levels. The simulation with WRF60k chemical IC/BCs reproduces the observed daytime $\mathrm{O}_{3}$ mixing ratios better than the control run, but the nighttime biases become worse. When the $\mathrm{BB}$ source is included (WRF60k_BB), the simulated $\mathrm{O}_{3}$ levels increase by about 10 ppbv mainly after 06:00 UTC on 21 July. Implementation of MOZART-4 chemical IC/BCs (MOZART_BB) further enhances background $\mathrm{O}_{3}$ levels, but these chemical IC/BCs have an insignificant impact (a few ppbv) on surface ozone. These results are in accordance with the analysis in Fig. 16.

\section{Summary and conclusions}

Transport and chemical transformation of well-defined New York City urban plumes over the North Atlantic Ocean were investigated using measurements on 20 and 21 July 2004 during the ICARTT field campaign and WRF-Chem simulations. A cold front passage associated with a mid-latitude cyclone swept away the pollutants from the days preceding this case, leading to favorable meteorological conditions to study characteristics of the NYC urban plumes and their transport and photochemical evolution over the North Atlantic Ocean. The NOAA WP-3D and DC-3 aircraft measurements characterized the 3-dimensional structure and chemical composition of the NYC urban plumes near the source region on 20 July and in a downwind region over the North Atlantic Ocean on 21 July.

The WP-3D in-situ measurements showed that CO levels in these NYC urban plumes were maintained, while $\mathrm{O}_{3}$ levels increased in the downwind portions of the plumes. The lidar measurements on the DC-3 aircraft demonstrated that urban plumes extended vertically up to about $2 \mathrm{~km}$ near New York City, but decreased to $1-1.5 \mathrm{~km}$ over the MBL over the North Atlantic Ocean. Negligible change in the CO (and $\mathrm{NO}_{\mathrm{y}}$ ) levels in the plumes measured between near the source area and over the North Atlantic Ocean suggests that the NYC urban plumes were efficiently transported during the two days with no significant influence of loss processes such as surface deposition. Meteorological measurements showed that the efficient transport mechanism is associated with the stably-stratified atmospheric thermal structure. The lower marine atmospheric layer (below $0.5 \mathrm{~km}$ ) over the North Atlantic Ocean was strongly stratified with a vertical gradient of potential temperature of over $10 \mathrm{~K} \mathrm{~km}^{-1}$, significantly suppressing vertical turbulent mixing over the marine atmosphere. When the NYC urban plumes extended in the CBL were advected over the stable MBL, the urban plumes vertically decoupled from the ocean surface in association with the cessation of turbulence. Consequently, the NYC urban plumes were efficiently transported in (isentropic) layers over the stable MBL while maintaining their structure.

The WRF-Chem simulated meteorology compared well to the observations from surface meteorological stations and the WP-3D aircraft, especially in terms of the vertical thermal structure of the atmosphere near New York City and over the North Atlantic Ocean. Because of good meteorological performance of WRF-Chem, the model was able to reproduce 

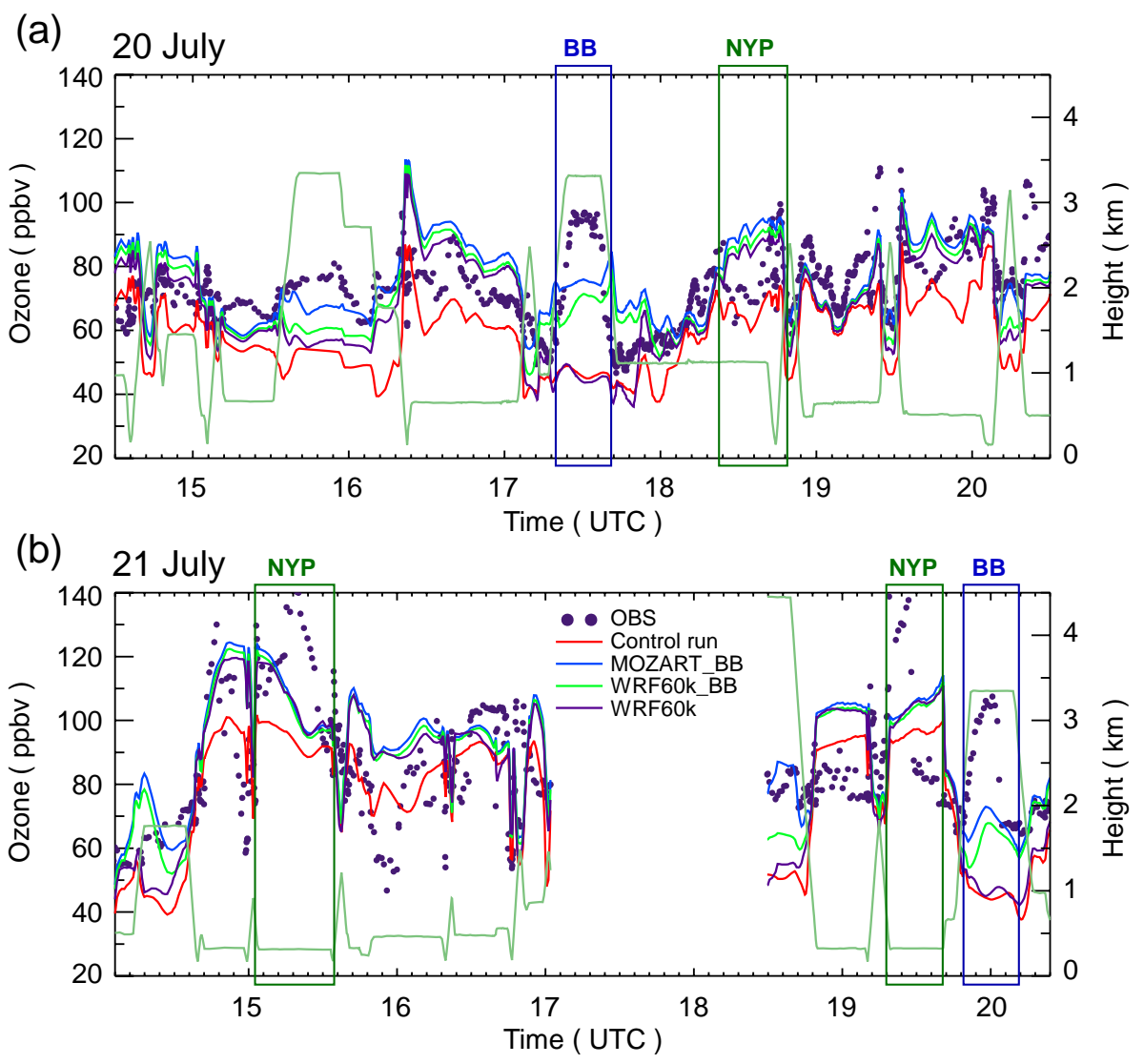

Fig. 15. (a) Observed and simulated $\mathrm{O}_{3}$ mixing ratios along the WP-3D flight tracks on (a) 20 July and (b) 21 July. "NYP" and "BB" denote NYC urban plumes and biomass-burning plumes as in Figs. 4 and 5.

chemical characteristics of the NYC urban plume observations made on the aircraft. The model simulation clearly demonstrated that daytime photochemistry produced the elevated ozone in the plumes transported from New York City over the North Atlantic Ocean on 20-21 July 2004. The model simulation showed that the anthropogenic emissions from the NYC metropolitan area were the main contributor to these plumes and that the research aircraft were indeed able to follow these urban plumes on flights occurring on successive days of plume transport.

The impact of chemical IC/BCs on the plume simulations over the northeastern US was investigated using output from a global chemical transport model (MOZART-4), Alaskan wildfire emissions, and anthropogenic/biogenic emissions from a larger North American domain that encompassed the higher-resolution domains used in the control simulation. All sensitivity simulations with dynamic chemical IC/BCs increased background $\mathrm{O}_{3}$ levels compared to the control simulation using prescribed static IC/BCs. Using the MOZART4 output as initial and boundary conditions increased average $\mathrm{O}_{3}$ mixing ratios by $6-8 \mathrm{ppbv}$ in the $1-3 \mathrm{~km}$ layer and by $2-3$ ppbv below $1 \mathrm{~km}$. Including the wildfire emissions enhanced average $\mathrm{O}_{3}$ levels by a similar amount as the MOZART-4 IC/BCs and by over $40 \mathrm{ppbv}$ in specific layers associated with BB plumes. The simulation including anthropogenic/biogenic emissions for most of North America enhanced $\mathrm{O}_{3}$ mixing ratios by $10-20 \mathrm{ppbv}$ in the NYC urban plumes and by $4-12 \mathrm{ppbv}$ on average in the layer below $3 \mathrm{~km}$. The simulated $\mathrm{O}_{3}$ profile in the upper atmosphere $(>3 \mathrm{~km})$ reproduced the observations well only when the MOZART-4 chemical IC/BCs were implemented. These sensitivity studies all point to the critical role that accurate chemical IC/BCs play in simulating local air quality. They also demonstrate the importance of long-range transport of $\mathrm{O}_{3}$ across the North American continent.

Comparison with surface $\mathrm{O}_{3}$ measurements showed that the control simulation reproduced the diurnal variation of the surface $\mathrm{O}_{3}$ mixing ratios at urban and non-urban stations. However, the observed daytime peak $\mathrm{O}_{3}$ levels were underestimated by about $10 \mathrm{ppbv}$ while the nocturnal $\mathrm{O}_{3}$ mixing ratios were overestimated up to $15 \mathrm{ppbv}$. The simulated surface $\mathrm{O}_{3}$ mixing ratios were sensitive to chemical IC/BCs because of the increased background $\mathrm{O}_{3}$ levels when considering more accurate chemical IC/BCs. Overall, including anthropogenic/biogenic emissions from across North America reduced daytime $\mathrm{O}_{3}$ model-measurement biases but 
(a) MOZART-4

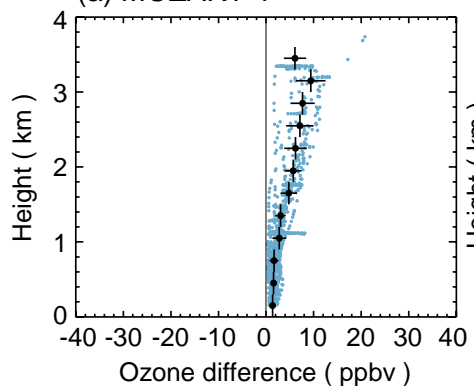

(d) MOZART-4

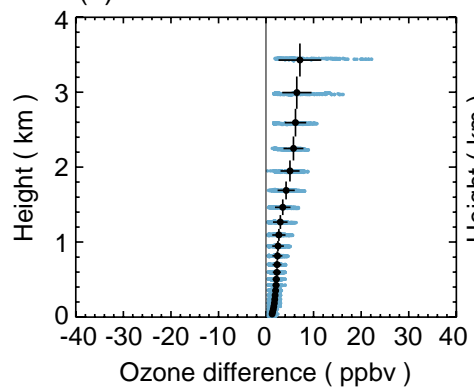

(b) BB source

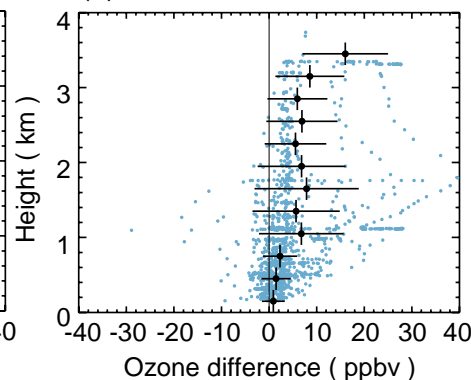

(e) BB source

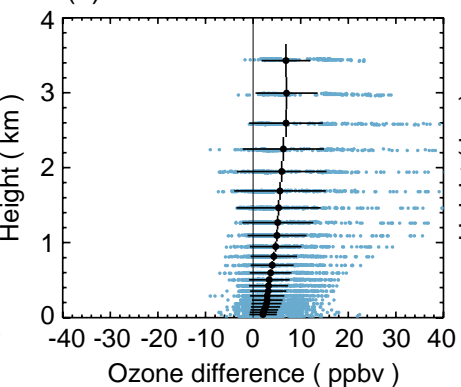

(c) NA emission

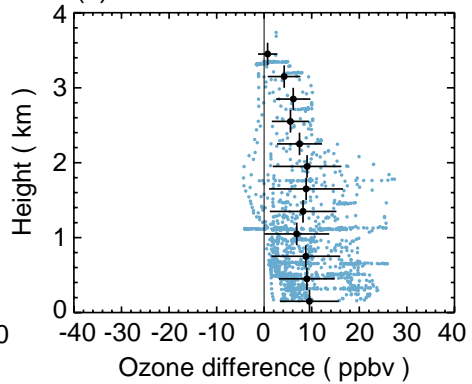

(f) NA emission

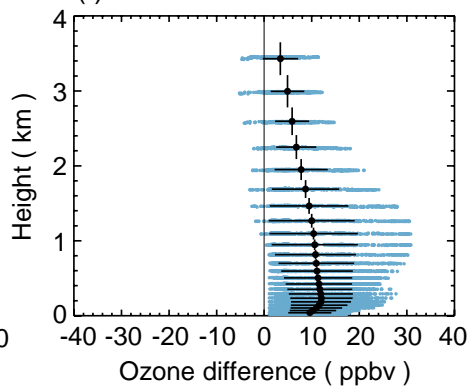

Fig. 16. Vertical distributions of $\mathrm{O}_{3}$ difference between two simulations. "MOZART-4" = MOZART_BB - WRF60k_BB, "BB source" = WRF60k_BB - WRF60k, and "NA emission" = WRF60k - control run, indicating the impact of chemical initial/boundary conditions by the MOZART-4 (a and d), biomass-burning source (b and e), and the North American anthropogenic/biogenic emissions (c and f) for the WP-3D (a-c) and DC-3 (d-f) flight tracks on 20 and 21 July. Binned height-intervals and corresponding mean and standard deviation are plotted.
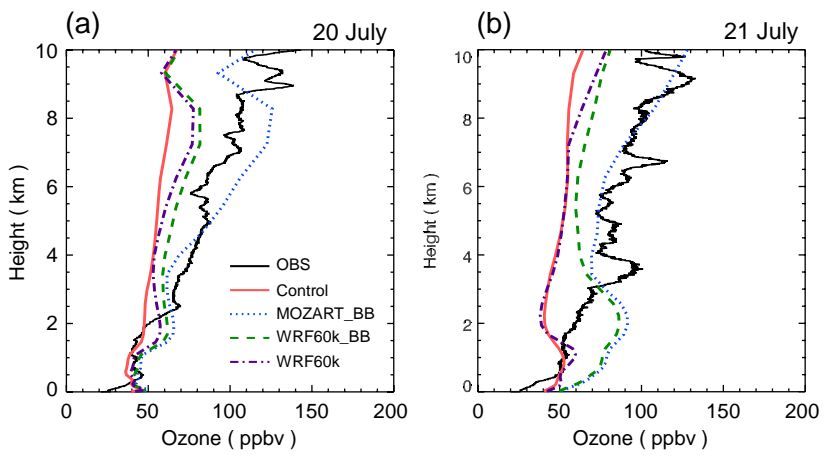

Fig. 17. Vertical distributions of observed and simulated $\mathrm{O}_{3}$ mixing ratios on (a) $20 \mathrm{July}\left(43.44^{\circ} \mathrm{N}, 69.28^{\circ} \mathrm{W}, 14: 13 \mathrm{UTC}\right)$ and (b) 21 July $\left(42.52^{\circ} \mathrm{N}, 70.67^{\circ} \mathrm{W}, 13: 48 \mathrm{UTC}\right)$ for the time and location of profiles by ozone-sondes launched from the NOAA Research Vessel (Thompson et al., 2007).

increased nighttime biases, including wildfire emissions improved model-observation agreement on some days but increased the $\mathrm{O}_{3}$ bias in others, and the MOZART-4 boundary conditions did not significantly impact the surface ozone simulation. (a) Urban stations

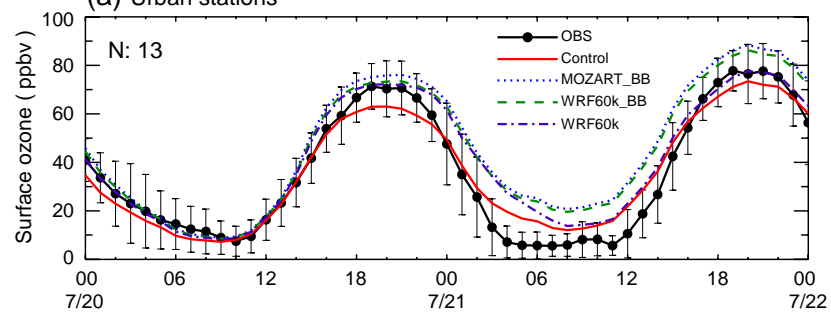

(b) Non-urban stations

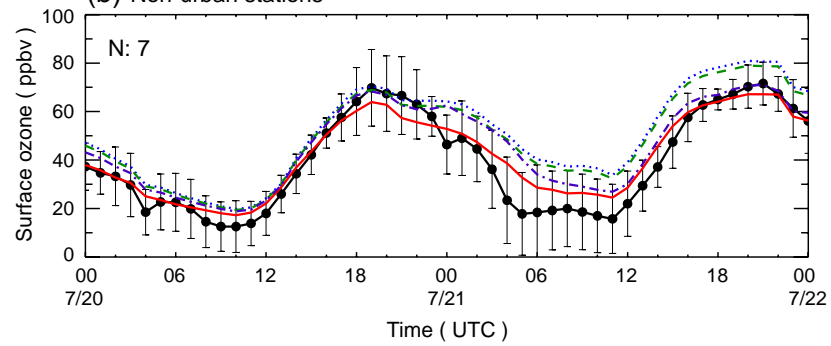

Fig. 18. Diurnal variations of observed and simulated $\mathrm{O}_{3}$ mixing ratios averaged for (a) 13 urban stations and (b) 7 non-urban stations near New York City $\left(75.0^{\circ} \mathrm{W}-73.0^{\circ} \mathrm{W}, 40.4^{\circ} \mathrm{N}-42.0^{\circ} \mathrm{N}\right)$. Vertical bars indicate spatial standard deviations of the observation. The twenty surface monitoring stations are classified into "urban" and "non-urban" classes following the land-use type assigned for the location of each station in the model. 
Acknowledgements. The authors would like to thank everyone involved with the NOAA WP-3D and DC-3 lidar aircraft measurements and the NOAA Research Vessel Ronald H. Brown ship measurements. The ozone sounding measurement was sponsored by NASA. We are grateful to Louisa Emmons from NCAR for providing the MOZART-4 results and Elaine Prins from the University of Wisconsin-Madison for providing access to GOES WF_ABBA fire products. We are also grateful to George Grell and Steven Peckham (NOAA/ESRL) for their assistance in using the WRF-Chem model. The authors are grateful to Eirh Yu Hsie for his management of NOAA ESRL computer systems. This work was funded by NOAA's Health of the Atmosphere Program.

Edited by: B. Vogel

\section{References}

Ackermann, I. J., Hass, H., Memmesheimer, M., Ebel, A., Binkowski, F. S., and Shankar, U.: Model aerosol dynamics model for Europe: Development and first applications, Atmos. Environ., 32(17), 2981-2999, 1998.

Andreae, M. and Merlet, P.: Emission of trace gases and aerosols from biomass burning, Global Biogeochem. Cy., 15(4), 955-966, 2001.

Angevine, W. M., Trainer, M., McKeen, S. A., and Berkowitz, C. M.: Mesoscale meteorology of the New England coast, Gulf of Maine, and Nova Scotia: Overview, J. Geophys. Res., 101(D22), 28893-28901, 1996.

Angevine, W. M., Senff, C. J., White, A. B., Williams, E. J., Koermer, J., Miller, S. T. K., Talbot, R., Johnston, P. E., McKeen, S. A., and Downs, T.: Coastal boundary layer influence on pollutant transport in New England, J. Appl. Meteorol., 43, 1425-1437, 2004.

Angevine, W. M., Tjernstrom, M., and Zagar, M.: Modeling of the coastal boundary layer and pollutant transport in New England, J. Appl. Meteorol. Clim., 45, 137-154, 2006.

Auvray, M. and Bey, I.: Long-range transport to Europe: Seasonal variations and implications for the European ozone budget, J. Geophys. Res., 110, D11303, doi:10.1029/2004JD005503, 2005.

Chen, F. and Dudhia, J.: Coupling an advanced land-surfacehydrology model with the Penn State-NCAR MM5 modeling system: Part I: Model description and implementation, Mon. Weather Rev., 129, 569-585, 2001.

Cooper, O. R., Moody, J. L., Parrish, D. D., Trainer, M., Ryerson, T. B., Holloway, J. S., Hubler, G., Fehsenfeld, F. C., and Evans, M. J.: Trace gas composition of midlatitude cyclones over the western North Atlantic Ocean: A conceptual model, J. Geophys. Res., 107(D7), 4056, doi:10.1029/2001JD000901, 2002.

Cooper, O. R., Parrish, D. D., Stohl, A., Trainer, M., Nédélec, P., Thouret, V., Cammas, J. P., Oltmans, S. J., Johnson, B. J., Tarasick, D., Leblanc, T., McDermid, I. S., Jaffe, D., Gao, R., Stith, J., Ryerson, T., Aikin, K., Campos, T., Weinheimer A., and Avery, M. A.: Increasing springtime ozone mixing ratios in the free troposphere over western North America, Nature, 463, 344-348, 2010.

Damian, V., Sandu, A., Damian, M., Potra, F., and Carmichael, G. R.: The Kinetic PreProcessor KPP-A software environment for solving chemical kinetics, Comput. Chem. Eng., 26, 1567-1579, 2002.
Daum, P. H., Kleinman, L. I., Newman, L., Luke, W. T., WeinsteinLloyd, J., Berkowitz, C. M., and Busness, K. M.: Chemical and physical properties of plumes of anthropogenic pollutants transported over the North Atlantic during the North Atlantic Regional Experiment, J. Geophys. Res., 101(D22), 29029-29042, 1996.

de Gouw, J. A., Warneke, C., Parrish, D. D., Holloway, J. S., Trainer, M., and Fehsenfeld, F.: Emission sources and ocean uptake of acetonitrile $\left(\mathrm{CH}_{3} \mathrm{CN}\right)$ in the atmosphere, J. Goephys. Res., 108(D11), 4329, doi:10.1029/2002JD002897, 2003.

de Gouw, J. A., Warneke, C., Stohl, A., Wollny, A. G., Brock, C. A., Cooper, O. R., Holloway, J. S., Trainer, M., Fehsenfeld, F. C., Atlas, E. L., Donnelly, S. G., Stroud, V., and Lueb, A.: Volatile organic compounds composition of merged and aged forest fire plumes from Alaska and western Canada, J. Goephys. Res., 111, D10303, doi:10.1029/2005JD006175, 2006.

Dudhia, J.: Numerical study of convection observed during the winter monsoon experiment using a mesoscale two-dimensional model, J. Atmos. Sci., 46, 3077-3107, 1989.

Emmons, L. K., Walters, S., Hess, P. G., Lamarque, J.-F., Pfister, G. G., Fillmore, D., Granier, C., Guenther, A., Kinnison, D., Laepple, T., Orlando, J., Tie, X., Tyndall, G., Wiedinmyer, C., Baughcum, S. L., and Kloster, S.: Description and evaluation of the Model for Ozone and Related chemical Tracers, version 4 (MOZART-4), Geosci. Model Dev., 3, 43-67, doi:10.5194/gmd3-43-2010, 2010.

Fang, Y., Fiore, A. M., Horowitz, L. W., Gnanadesikan, A., Levy, H., Hu, Y., and Russell, A. G.: Estimating the contribution of strong daily export events to total pollutant export from the United States in summer, J. Geophys. Res., 114, D23302, doi:10.1029/2008JD010946, 2009.

Fehsenfeld, F. C., Ancellet, G., Bates, T. S., Goldstein, A. H., Hardesty, R. M., Honrath, R., Law, K. S., Lewis, A. C., Leaitch, R., McKeen, S., Meagher, J., Parrish, D. D., Pszenny, A. A. P., Russell, P. B., Schlager, H., Seinfeld, J., Talbot, R., and Zbinden, R.: International consortium for atmospheric research on transport and transformation (ICARTT): North America to EuropeOverview of the 2004 summer field study, J. Geophys. Res., 111, D23S01, doi:10.1029/2006JD007829, 2006.

Freitas, S. R., Longo, K. M., Silva Dias, M., Silva Dias, P., Chatfield, R., Prins, E., Artaxo, P., Grell, G., and Recuero, F.: Monitoring the transport of biomass burning emissions in South America, Environ. Fluid Mech., 5, 135-167, 2005.

Freitas, S. R., Longo, K. M., Chatfield, R., Latham, D., Silva Dias, M. A. F., Andreae, M. O., Prins, E., Santos, J. C., Gielow, R., and Carvalho Jr., J. A.: Including the sub-grid scale plume rise of vegetation fires in low resolution atmospheric transport models, Atmos. Chem. Phys., 7, 3385-3398, doi:10.5194/acp-7-33852007, 2007.

Giglio, L., Descloitres, J., Justice, C. O., and Kaufman, Y. J.: An enhanced contextual fire detection algorithm for MODIS, Remote Sens. Environ., 87, 273-282, 2003.

Grabowski, W.: Coupling cloud processes with the large-scale dynamics using the cloud-resolving convection parameterization, J. Atmos. Sci., 58, 978-997, 2001.

Grell, G. A. and Devenyi, D.: A generalized approach to parameterizing convection combining ensemble and data assimilation techniques, Geophys. Res. Lett., 29(14), 1693, doi:10.1029/2002GL015311, 2002. 
Grell, G. A., Peckham, S. E., Schmitz, R., McKeen, S. A., Frost, G., Skamarock, W., and Eder, B.: Fully coupled "online" chemistry within the WRF model, Atmos. Environ., 39, 6957-6975, 2005.

Holt, T. R. and Pullen, J.: Urban canopy modeling of the New York City metropolitan area: A comparison and validation of single- and multilayer parameterizations, Mon. Weather Rev., 135, 1906-1927, 2007.

Hong, S.-Y., Dudhia, J., and Chen, S.-H.: A revised approach to ice microphysical processes for the bulk parameterization of cloud and precipitation, Mon. Weather Rev., 132, 103-120, 2004.

Jacob, D. J., Logan, J. A., and Murti, P. P.: Effect of rising Asian emissions on surface ozone in the United States, Geophys. Res. Lett., 26, 2175-2178, 1999.

Janjic, Z. I.: The step mountain eta coordinate: Physical package, Mon. Weather Rev., 118, 1561-1575, 1990.

Lee, S.-H.: Further development of the Vegetated Urban Canopy Model including a grass-covered surface parametrization and photosynthesis effects, Bound.-Layer Meteor., 140, 315-342, doi:10.1007/s10546-011-9603-7, 2011.

Lee, S.-H., McKeen, S. A., Angevine, W. M., Frost, G. J., Kim, S.-W., and Trainer, M.: Impact of an urban land surface parameterization on the transport and dispersion of gaseous air pollutant, The 7th International Conference on Urban Climate, Yokohama, Japan, 29 June-3 July, 2009.

Li, Q., Jacob, D. J., Bey, I., Palmer, P. I., Duncan, B. N., Field, B. D., Martin, R. V., Fiore, A. M., Yantosca,, R. M., Parrish, D. D., Simmonds, P. G., and Oltmans, S. J.: Transatlantic transport of pollution and its effects on surface ozone in Europe and North America, J. Geophys. Res., 107(D13), 4166, doi:10.1029/2001JD001422, 2002.

Li, Q., Jacob, D. J., Park, R., Wang, Y., Heald, C. L., Hudman, R., Yantosca, R. M., Martin, R. V., and Evans, M.: North American pollution outflow and the trapping of convectively lifted pollution by upper-level anticyclone, J. Goephys. Res., 110, D10301, doi:10.1029/2004JD005039, 2005.

Liu, S. C., McKeen, S. A., Hsie, E.-Y., Lin, X., Kelly, K. K., Bradshaw, J. D., Sandholm, S. T., Browell, E. V., Gregory, G. L., Sachse, G. W., Bandy, A. R., Thornton, D. C., Blake, D. R., Rowland, F. S., Newell, R., Heikes, B. G., Singh, H., and Talbot, R. W.: Model study of tropospheric trace species distributions during PEM-West A, J. Geophys. Res., 101(D1), 2073-2085, 1996.

Longo, K. M., Freitas, S. R., Andreae, M. O., Setzer, A., Prins, E., and Artaxo, P.: The Coupled Aerosol and Tracer Transport model to the Brazilian developments on the Regional Atmospheric Modeling System (CATT-BRAMS) - Part 2: Model sensitivity to the biomass burning inventories, Atmos. Chem. Phys., 10, 5785-5795, doi:10.5194/acp-10-5785-2010, 2010.

Madronich, S.: Photodissociation in the atmosphere: 1. Actinic flux and the effects of ground reflections and clouds, J. Geophys. Res., 92(D8), 9740-9752, doi:10.1029/JD092iD08p09740, 1987.

Mao, H., Talbot, R., Troop, D., Johnson, R., Businger, S., and Thompson, A. M.: Smart balloon observations over the North Atlantic: O3 data analysis and modeling, J. Geophys. Res., 111, D23S56, doi:10.1029/2005JD006507, 2006.

McKeen, S. A., Wotawa, G., Parrish, D. D., Holloway, J. S., Buhr, M. P., Hubler, G., Fehsenfeld, F. C., and Meagher, J. F.: Ozone production from Canadian wildfires during June and July of 1995, J. Geophys. Res., 107(D14), 4192,
doi:10.1029/2001JD000697, 2002.

Mlawer, E. J., Taubman, S. J., Brown, P. D., Iacono, M. J., and Clough S. A.: Radiative transfer for inhomogeneous atmosphere: RRTM, a validated correlated-k model for the long-wave, J. Geophys. Res., 102(D14), 16663-16682, doi:10.1029/97JD00237, 1997.

Neuman, J. A., Parrish, D. D., Trainer, M., Ryerson, T. B., Holloway, J. S., Nowak, J. B., Swanson, A., Flocke, F., Roberts, J. M., Brown, S. S., Stark, H., Sommariva, R., Stohl, A., Peltier, R., Weber, R., Wollny, A. G., Sueper, D. T., Hubler, G., and Fehsenfeld, F. C.: Reactive nitrogen transport and photochemistry in urban plumes over the North Atlantic Ocean, J. Geophys. Res., 111, D23S54, doi:10.1029/2005JD007010, 2006.

Owen, R. C., Cooper, O. R., Stohl, A., and Honrath, R. E.: An analysis of the mechanisms of North American pollutant transport to the central North Atlantic lower free troposphere, J. Geophys. Res., 111, D23S58, doi:10.1029/2006JD007062, 2006.

Park, R. J., Jacob, D. J., Field, B. D., Yantosca, R. M., and Chin, M.: Natural and transboundary pollution influences on sulfate-nitrate-ammonium aerosols in the United States: Implications for policy, J. Geophys. Res., 109, D15204, doi:10.1029/2003JD004473, 2004.

Parrish, D., Trainer, M., Holloway, J., Yee, J., Warshawsky, M., and Fehnsenfeld, F.: Relationships between ozone and carbon monoxide at surface sites in the North Atlantic region, J. Geophys. Res., 103, 13357-13376, 1998.

Prins, E., Feltz, J., Menzel, W., and Ward, D.: An overview of GOES-8 diurnal fire and smoke results for SCAR-B and 1995 fire season in South America, J. Geophys. Res., 103(D24), 3182131835, 1998.

Pu, R., Li, Z., Gong, P., Csiszar, I., Fraser, R., Hao, W.-M., Kondragunta, S., and Weng, F.: Development and analysis of a 12year daily $1-\mathrm{km}$ forest fire dataset across North America from NOAA/AVHRR data, Remote Sens. Environ., 108, 198-208, 2007.

Real, E., Law, K. S., Schlager, H., Roiger, A., Huntrieser, H., Methven, J., Cain, M., Holloway, J., Neuman, J. A., Ryerson, T., Flocke, F., de Gouw, J., Atlas, E., Donnelly, S., and Parrish, D.: Lagrangian analysis of low altitude anthropogenic plume processing across the North Atlantic, Atmos. Chem. Phys., 8, 77377754, doi:10.5194/acp-8-7737-2008, 2008.

Schell, B., Ackermann, I. J., Hass, H., Binkowski, F. S., and Ebel, A.: Modeling the formation of secondary organic aerosol within a comprehensive air quality model system, J. Geophys. Res., 106(D22), 28275-28293, doi:10.1029/2001JD000384, 2001.

Skamarock, W. C., Klemp, J. B., Dudhia, J., Gill, D. O., Barker, D. M., Duda, M. G., Hwang, X.-Y., Wang, W., and Powers, J. G.: A description of the advanced research WRF version 3, Technical Note 475+STR, National Center for Atmospheric Research, Boulder, CO, USA, 2008.

Singh, H. B., Brune, W. H., Crawford, J. H., Jacob, D. J., and Russell, P. B.: Overview of the summer 2004 intercontinental chemical transport experiment - North America (INTEX-A), J. Geophys. Res., 111, D24S01, doi:10.1029/2006JD007905, 2006.

Song, C.-K., Byun, D. W., Pierce, R. B., Alsaadi, J. A., Schaack, T. K., and Vukovich, F.: Downscale linkage of global model output for regional chemical transport modeling: Method and general performance, J. Geophys. Res., 113, D08308, doi:10.1029/2007JD008951, 2008. 
Stockwell, W. R., Kirchner, F., Kuhm, M., and Seefeld, S.: A new mechanism for regional atmospheric chemistry modeling, J. Geophys. Res., 102(D22), 25847-25879, doi:10.1029/97JD00849, 1997.

Tang, Y. H., Lee, P., Tsidulko, M., Huang, H. C., McQueen, J. T., DiMego, G. J., Emmons, L. K., Pierce, R. B., Thompson, A. M., Lin, H. M., Kang, D., Tong, D., Yu, S. C., Mathur, R., Pleim, J. E., Otte, T. L., Pouliot, G., Young, J. O., Schere, K. L., Davidson, P. M., and Stajner, I.: The impact of chemical lateral boundary conditions on CMAQ predictions of tropospheric ozone over the continental United States, Environ. Fluid Mech., 9, 43-58, doi10.1007/s10652-008-9092-5, 2009.

Thompson, A. M., Stone, J. B., Witte, J. C., Miller, S. K., Pierce, R. B., Chatfield, R. B., Oltmans, S. J., Cooper, O. R., Loucks, A. L., Taubman, B. F., Johnson, B. J., Joseph, E., Kucsera, T. L., Merrill, J. T., Morris, G. A., Hersey, S., Forbes, G., Newchurch, M. J., Schmidlin, F. J., Tarasick, D. W., Thouret, V., and Cammas J.-P.: Intercontinental chemical transport experiment ozonesonde network study (IONS) 2004: 1. Summertime upper troposphere/lower stratosphere ozone over northeastern North America, J. Geophys. Res., 112, D12S12, doi:10.1029/2006JD007441, 2007.

Trainer, M., Ridley, B. A., Buhr, M. P., Kok, G., Walega, J., Hubler, G., Parrish, D. D., and Fehsenfeld, F. C.: Regional ozone and urban plumes in the southeastern United States: Birmingham, a case study, J. Geophys. Res., 100(D9), 18823-18834, 1995.
Turquety, S., Logan, J. A., Jacob, D. J., Hudman, R. C., Leung, F. Y., Heald, C. L., Yantosca, R. M., Wu, S., Emmons, L. K., Edwards, D. P., and Sachse, G. W.: Inventory of boreal fire emissions for North America in 2004: Importance of peat burning and pyroconvective injection, J. Geophys. Res., 112, D12S03, doi:10.1029/2006JD007281, 2007.

Wang, H., Jacob, D. J., Le Sager P., Streets, D. G., Park, R. J., Gilliland, A. B., and van Donkelaar, A.: Surface ozone background in the United States: Canadian and Mexican pollution influences, Atmos. Environ., 43, 1310-1319, 2009a.

Wang, H., Skamarock, W. C., and Feingold, G.: Evaluation of scalar advection schemes in the Advanced Research WRF model using large-eddy simulations of aerosol-cloud interactions, Mon. Weather Rev., 137, 2547-2558, 2009b.

Ward, E., Susott, R., Kaufman, J., Babbit, R., Cummings, D., Dias, B., Holben, B., Kaufman, Y., Rasmussen, R., and Setzer, A.: Smoke and fire characteristics for cerrado and deforestation burns in Brazil: BASE-B experiment, J. Geophys. Res., 97(D13), 14601-14619, 1992.

Willmott, C. J.: On the validation of models. Phys. Geogr., 2, 184194, 1981. 